\title{
FENÓIS TOTAIS NO CAFEEIRO EM RAZÃO DAS FASES DE FRUTIFICAÇÃO E DO CLIMA
}

\section{Paula Rodrigues Salgado}

\begin{abstract}
Dissertação apresentada à Escola Superior de Agricultura "Luiz de Queiroz", Universidade de São Paulo, para obtenção do título de Mestre em Agronomia, Área de Concentração: Fitotecnia.
\end{abstract}

P I R A C I C A B A

Estado de São Paulo - Brasil

Dezembro - 2004 


\title{
FENÓIS TOTAIS NO CAFEEIRO EM RAZÃO DAS FASES DE FRUTIFICAÇÃO E DO CLIMA
}

\section{Paula Rodrigues Salgado}

Engenheiro Agrônomo

\section{Orientador: Prof. Dr. JOSÉ LAÉRCIO FAVARIN}

\author{
Dissertação apresentada à Escola Superior \\ de Agricultura "Luiz de Queiroz", \\ Universidade de São Paulo, para obtenção do \\ título de Mestre em Agronomia, Área de \\ Concentração: Fitotecnia.
}

P I R A C I C A B A

Estado de São Paulo - Brasil

Dezembro - 2004 


\section{Dados Internacionais de Catalogação na Publicação (CIP) DIVISÃO DE BIBLIOTECA E DOCUMENTAÇÃO - ESALQ/USP}

\section{Salgado, Paula Rodrigues}

Fenóis totais no cafeeiro em razão das fases de frutificação e do clima / Paula

Rodrigues Salgado. - - Piracicaba, 2004.

60 p. : il.

Dissertação (Mestrado) - - Escola Superior de Agricultura Luiz de Queiroz, 2004.

Bibliografia.

1. Café 2. Clima 3. Crescimento 4. Energia solar 5. Fenologia 6. Folhas - Plantas

7. Frutificação 8. Insolação 9. Temperatura atmosférica I. Título

CDD 633.73

"Permitida a cópia total ou parcial deste documento, desde que citada a fonte - O autor" 


\section{DEDICO}

ao meu amado pai, José Antonio Salgado, que agora vive em um mundo melhor. 


\section{AGRADECIMENTOS}

Ao meu orientador, Professor Doutor José Laércio Favarin, pela orientação, dedicação, compreensão e apoio nos momentos dificeis;

à Professora Doutora Roseli Aparecida Leandro, pela disponibilidade e ajuda na parte das análises estatísticas;

aos integrantes da banca Examinadora do Exame de Qualificação, pela disposição;

à Engenheira Agrônoma Regina Peçanha do Centro de Energia Nuclear na Agricultura - CENA/USP, pelas análises laboratoriais;

ao Engenheiro Agrônomo Edson Teramoto e aos funcionários do Departamento de Produção Vegetal pela assistência nos trabalhos de campo;

ao Engenheiro Agrônomo Euro Detomini, pelas informações estatísticas e amizade;

à minha mãe, Maria de Lourdes, pela força e estabilidade emocional;

aos meus irmãos, Mouzart e Thais, aos meus cunhados, Renata e Tomas, e aos meus lindos sobrinhos, Gabriel, Laura e Philipp, pelos momentos de alegria e harmonia;

ao Rafael (Bota), pelo carinho e compreensão em todos os momentos;

à minha grande amiga, Giuliana (Tafassiu), por todos os momentos passados juntas e pelo apoio;

à República REBOQ (ESALQ/USP), pelo amparo e amizade; 
à Luciana (Bezerra) e Lorena (K-til), pela ajuda nas coletas de dados;

às amigas e colegas acadêmicas, Maria Luiza (Di-Lúvio), Mariana

(Relp) e Priscila (Malhada), pela amizade, apoio e união; aos amigos da F-2002, pelos momentos felizes na Gloriosa. 


\section{SUMÁRIO}

Página

LISTA DE FIGURAS ............................................................. viii

LISTA DE TABELAS ............................................................ xi

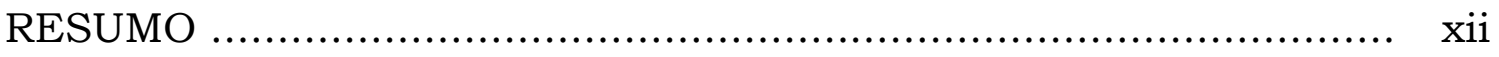

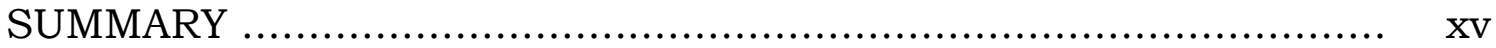

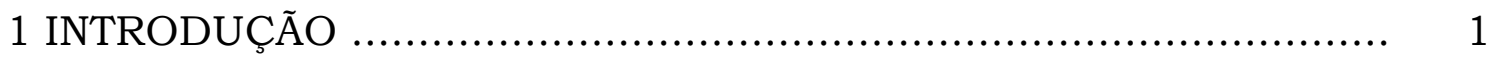

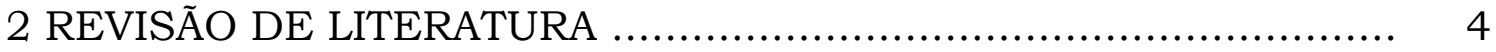

2.1 Produção e função dos compostos fenólicos ........................... 4

2.2 Resistência induzida .................................................. 8

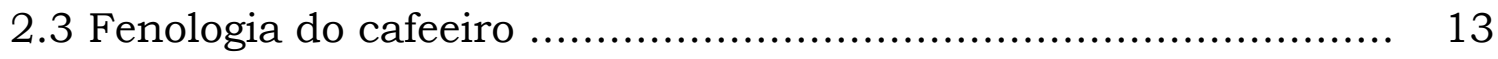

3 MATERIAL E MÉTODOS .................................................. 20

3.1 Área experimental e material genético .................................. 20

3.2 Manejo e condução das plantas ..................................... 21

3.3 Avaliação dos teores de fenóis totais ..................................... 23

3.4 Avaliação do crescimento vegetativo ................................. 25 
3.4.1 Taxa de crescimento em diâmetro do caule (TDC; $m m$ dia $^{-1}$ ) ... $\quad 25$

3.4.2 Taxa de crescimento em altura da planta $\left(\mathrm{TCH} ; \mathrm{cm} \mathrm{dia}{ }^{-1}\right) \ldots \ldots .26$

3.4.3 Taxa de crescimento de ramos plagiotrópicos (TCR; $\left.\mathrm{cm} \mathrm{dia}{ }^{-1}\right)$.. 26

3.5 Dados climatológicos .................................................. 27

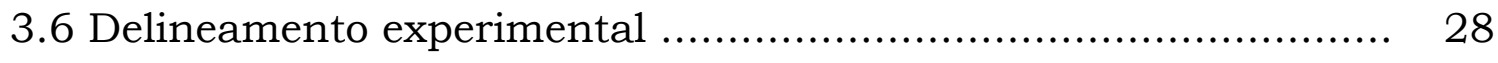

4 RESULTADOS E DISCUSSÃO ........................................... 29

4.1 Produção de fenóis nas plantas ............................................ 29

4.1.1 Folhas dreno e fonte .................................................... 33

4.1.2 Fase de frutificação ................................................... 36

4.2 Teor foliar de fenóis em relação ao clima ................................. 45

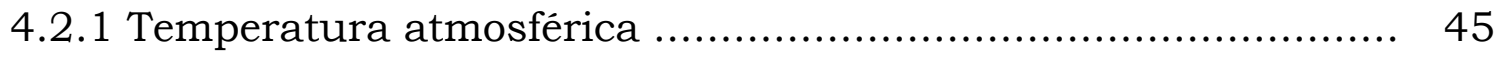

4.2.2 Radiação Global ........................................................ 47

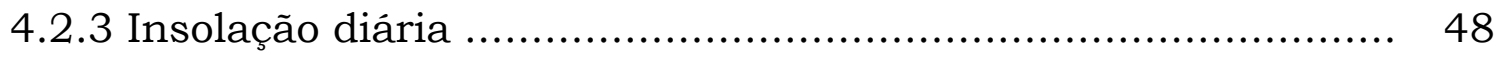

5 CONCLUSÕES .................................................................. 50

REFERÊNCIAS BIBLIOGRÁFICAS ....................................... 51 


\section{LISTA DE FIGURAS}

Página

1 Esquema das fases vegetativas e reprodutivas do cafeeiro arábica durante 24 meses ................................................

2 Curva de regressão da quantidade de matéria seca (y: g cova-1) acumulada pelo fruto do cafeeiro, em função do desenvolvimento (x: dia)

3 Área experimental de café (cv. Obatã IAC 1669-20) da Escola Superior de Agricultura "Luiz de Queiroz", Universidade de São Paulo, Piracicaba, SP...................................................... 20

4 Folha dreno (a) e folha fonte (b) amostradas nas fases de frutificação para a análise dos teores de fenóis totais

5 Teores de fenóis totais $\left(\mu \mathrm{g} \mathrm{g}^{-1}\right)$ nas folhas dreno das plantas com e sem produção de café

6 Teores de fenóis totais $\left(\mu \mathrm{g} \mathrm{g}^{-1}\right)$ nas folhas fonte das plantas com e sem produção de café 
7 Teores médios de fenóis totais $\left(\mu \mathrm{g} \mathrm{g}^{-1}\right)$ nas folhas dreno e fonte das plantas com e sem produção de café

8 Teores de fenóis totais $\left(\mu \mathrm{g} \mathrm{g}^{-1}\right)$ nas plantas em razão da produção de café beneficiado (sacas ha-1)

9 Teores de fenóis totais ( $\mu \mathrm{g} \mathrm{g}^{-1}$ ) nas folhas dreno e fonte das plantas com produção de café

10 Teores de fenóis totais $\left(\mu \mathrm{g}^{-1}\right)$ nas folhas dreno e fonte das plantas sem produção de café

11 Teores de fenóis totais ( $\mu \mathrm{g} \mathrm{g}^{-1}$ ) nas folhas dreno das plantas sem produção de café nos períodos equivalentes as fases de frutificação

12 Teores de fenóis totais ( $\mu \mathrm{g} \mathrm{g}^{-1}$ ) nas folhas fonte das plantas sem produção de café nos períodos equivalentes as fases de frutificação

13 Taxa de crescimento do diâmetro (TCD; $\mathrm{mm} \mathrm{dia}^{-1}$ ) (a) e taxa de crescimento do comprimento dos ramos plagiotrópicos (TCR; $\mathrm{cm}$ dia-1 $^{-1}$ (b) das plantas com e sem produção de café, no período entre as fases fenológicas E1-E2 (frutos em chumbinho e em expansão) 
14 Taxa de crescimento do diâmetro (TCD; $\mathrm{mm} \mathrm{dia}^{-1}$ ) (a) e taxa de crescimento do comprimento dos ramos plagiotrópicos (TCR; $\mathrm{cm}$ dia $^{-1}$ ) (b) das plantas com e sem produção de frutos, no período entre as fases fenológicas E3-E4 (frutos em granação e em início da maturação)

15 Taxa de crescimento da altura $\left(\mathrm{TCH} ; \mathrm{cm} \mathrm{dia}^{-1}\right)$ das plantas com e sem produção de frutos, nos períodos entre as fases fenológicas E1 - E2 (frutos em "chumbinho" e em expansão) (a) e E3-E4 (b) (frutos em granação e em início da maturação) ........

16 Teores de fenóis totais ( $\mu \mathrm{g} \mathrm{g}^{-1}$ ) nas folhas dreno (a, c, e) e folhas fonte $(b, d, f)$ das plantas com produção em razão das fases fenológicas da frutificação e da variação da temperatura (média, máxima e mínima; $\left.{ }^{\circ} \mathrm{C}\right)$

17 Teores de fenóis totais $\left(\mu \mathrm{g} \mathrm{g}^{-1}\right)$ nas folhas dreno (a) e fonte (b) das plantas com produção em razão das fases fenológicas de frutificação e da variação da radiação global $\left(\mathrm{MJ} \mathrm{m}^{-2} \mathrm{dia}^{-1}\right)$.........

18 Teores de fenóis totais $\left(\mu \mathrm{g} \mathrm{g}^{-1}\right)$ nas folhas dreno (a) e fonte (b) das plantas com produção em razão das fases fenológicas de frutificação e da variação da insolação diária $\left(\mathrm{h}\right.$ dia $\left.^{-1}\right)$ 


\section{LISTA DE TABELAS}

Página

1 Resultados da análise química foliar de macronutrientes em plantas de cafeeiro com e sem produção, em março de

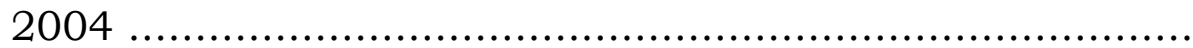

2 Teores médios de fenóis totais $\left(\mu \mathrm{g} \mathrm{g}^{-1}\right)$ nas folhas dreno das plantas sem produção, valores de $t$ observados $e$ hipótese da nulidade nos periodos das fases de frutificação do café

3 Teores médios de fenóis totais $\left(\mu \mathrm{g} \mathrm{g}^{-1}\right)$ nas folhas fonte das plantas sem produção, valores de $t$ observados e hipótese da nulidade nos períodos das fases de frutificação do café 


\title{
FENÓIS TOTAIS NO CAFEEIRO EM RAZÃO DAS FASES DE FRUTIFICAÇÃO E DO CLIMA
}

\author{
Autora: PAULA RODRIGUES SALGADO \\ Orientador: Prof. Dr. JOSÉ LAÉRCIO FAVARIN
}

\section{RESUMO}

Os vegetais apresentam defesa natural contra os fatores externos, bióticos e abióticos, por meio da síntese de compostos fenólicos no metabolismo secundário, as quais variam com as fases fenológicas e com o clima. O aumento dos compostos fenólicos nas plantas está, diretamente, relacionado com a resistência à infecção por patógenos e à infestação de pragas. Entretanto, pouco se sabe sobre a variação dos teores dessa substância durante os estádios fenológicos do cafeeiro, em particular, nas fases de frutificação, e em razão das condições climáticas. Tais conhecimentos são fundamentais para a previsão dos riscos de ataques aos vegetais, uma vez que a defesa natural da planta deve mudar ao longo do ciclo. O experimento foi realizado em uma cultura de Coffea arabica L., cultivar Obatã IAC 1669-20, instalada no campo experimental do Departamento de Produção Vegetal, da Escola Superior de Agricultura "Luiz de Queiroz", Universidade de São Paulo, Piracicaba/SP. Para a realização do experimento foi adotado o delineamento experimental inteiramente casualizado, utilizando quatro 
tratamentos (plantas com e sem frutos - folhas dreno e plantas com e sem frutos - folhas fonte) e cinco repetições constituidas por plantas individuais. Após a análise de variância dos resultados foi aplicado o teste $\mathrm{t}$ de Student ao nível de 5 \% de significância para a comparação das médias entre os tratamentos. Os teores de fenóis totais $\left(\mu \mathrm{g} \mathrm{g}^{-1}\right)$ foram extraidos das folhas maduras (fonte) e novas (dreno) e analisados em relação à produção de café, fenologia e clima. As variáveis climáticas adotadas foram temperatura atmosférica (média, mínima e máxima; ${ }^{\circ}$ ), radiação global $\left(\mathrm{MJ} \mathrm{m}^{-2}\right.$ dia $\left.^{-1}\right)$ e insolação diária (h dia-1). Durante a condução do experimento foram realizadas avaliações de altura da planta (cm), diâmetro do caule $(\mathrm{mm})$ e comprimento de ramos plagiotrópicos $(\mathrm{cm})$ para determinar as respectivas taxas de crescimento vegetativo das plantas. As quantidades de fenóis totais determinadas nas plantas com produção $\left(17.40 \mu \mathrm{g} \mathrm{g}^{-1}\right.$ e $13.89 \mu \mathrm{g} \mathrm{g}^{-1}$ folhas dreno e fonte, respectivamente) e sem produção de café (18.65 $\mu \mathrm{g} \mathrm{g}^{-1}$ e $12.76 \mu \mathrm{g}$ $\mathrm{g}^{-1}$ folhas dreno e fonte, nessa ordem) não variaram. No entanto, a concentração de fenóis totais nas folhas novas (dreno) das plantas com e sem produção de café foi maior que a quantidade determinada nas folhas maduras (fonte), da ordem de $25 \%$ e $46 \%$, respectivamente. A sintese de fenóis nas fases de expansão (16.35 $\left.\mu \mathrm{g} \mathrm{g}^{-1}\right)$ e granação dos frutos $\left(14.68 \mu \mathrm{g} \mathrm{g}^{-1}\right)$ foi $31 \%$ inferior em relação às quantidades determinadas na fase de maior produção dessas substâncias - fruto em maturação (21.24 $\left.\mu \mathrm{g} \mathrm{g}^{-1}\right)$. A metabolização de fenóis totais depende, indiretamente, da temperatura $\left({ }^{\circ} \mathrm{C}\right)$ e da radiação global $\left(\mathrm{MJ} \mathrm{m}^{-2} \mathrm{dia}^{-1}\right)$, apresentando tendência inversa em relação a estas variáveis climáticas. A orientação do manejo fitossanitário deve levar em consideração as épocas em que há comprometimento da defesa natural da planta, em relação à produção de substâncias protetivas - os fenóis. 
Palavras-chave: Coffea arabica L., folhas maduras (fonte), folhas novas (dreno), temperatura atmosférica, radiação global e insolação diária. 


\title{
TOTAL PHENOLS IN THE COFFEE TREE DUE TO THE FRUCTIFICATION PHASES AND THE CLIMATE
}

\author{
Author: PAULA RODRIGUES SALGADO \\ Adviser: Prof. Dr. JOSÉ LAÉRCIO FAVARIN
}

\section{SUMMARY}

The vegetables show a natural defense against external factors, biotic and abiotic, by the synthesis of the phenolic compounds in the secondary metabolism, which varies with the maturity state and with the climate. The increase of phenolic compounds in the plants is directly related to the resistance to the infection thought pathogens and insect infestation. However, little is known about the variation in the content of this substance during the maturity state of the coffee tree, particularly in the fructification phases due to the climatic variations. Such knowledge is the base for the risks analyses of attacks to vegetables, since the natural defense of the plant shall change during the cycle. The experiment was carried out in a Coffea arabica L. crop, to cultivar Obatã IAC 1669-20, installed in the experimental field of the department of vegetal production of the Escola Superior de Agricultura "Luiz de Queiroz", University of São Paulo, Piracicaba/SP. For the accomplishment of the experiment it was adopted a totally randomized experimental design, using four treatments 
(plants with and without fruits - drain leaves and plants with and without fruits - source leaves) and five repetitions consisting of individual plants. After analysing the variance of the results it was applied Student $t$ test at the level of $5 \%$ of significance to compare the averages between the treatments. The total phenol grade $\left(\mu \mathrm{g} \mathrm{g}^{-1}\right)$ have been extracted from the mature (source) and new (drain) leaves and have been analyzed in relation to the coffee yield, phenology and climate. The climatic conditions adopted were atmospheric temperature (average, minimum and maximum; $\left.{ }^{\circ} \mathrm{C}\right)$, global radiation $\left(\mathrm{MJ} \mathrm{m}^{-2}\right.$ day $\left.^{-1}\right)$ and daily insolation ( $\mathrm{h}$ day $^{-1}$ ). During the conduction of the experiment it was analyzed the evaluations of the height $(\mathrm{cm})$, diameter $(\mathrm{mm})$ and length of the reproductive branches $(\mathrm{cm})$ to determine the respective vegetative growth rates of the plants. The determined amounts of total phenols in the plants with production $\left(17.40 \mu \mathrm{g} \mathrm{g}^{-1}\right.$ and $13.89 \mu \mathrm{g} \mathrm{g}^{-1}$ drain and source leaves, respectively) and without coffee production $\left(18.65 \mu \mathrm{g} \mathrm{g}^{-1}\right.$ and $12.76 \mu \mathrm{g} \mathrm{g}^{-1}$ drain and source leaves, respectively) did not varied. However, the total phenol concentrations in new leaves of the plants with and without coffee production were greater than the amount determined in mature leaves around $25 \%$ and $46 \%$, respectively. The secondary substance synthesis in the phases of expansion $\left(16.35 \mu \mathrm{g} \mathrm{g}^{-1}\right)$ and grain filling of the fruits $\left(14.68 \mu \mathrm{g} \mathrm{g}^{-1}\right)$ was $31 \%$ lower than the amounts determined in the phase of the greatest production of these substances - fruit in maturation $\left(21.24 \mu \mathrm{g} \mathrm{g} \mathrm{g}^{-1}\right)$. The total phenol metabolization depends indirectly on the temperature $\left({ }^{\circ} \mathrm{C}\right)$ and on the global radiation $\left(\mathrm{MJ} \mathrm{m}^{-2} \mathrm{day}^{-1}\right)$, presenting inverse trend in relation to these climatic variable. The orientation of the crop protection managing shall take into consideration the period when it has endangerment of the natural defense of the plant. 
Key - words: Coffea arabica L., mature leaves (source), new leaves (drain), atmospheric temperature, global radiation and daily insolation. 


\section{INTRODUÇÃO}

Durante o desenvolvimento do cafeeiro as fases vegetativas e reprodutivas ocorrem concomitantemente, havendo competição por fotoassimilados entre ambas. Essa é a principal causa da bienalidade da produção da cultura, pois a frutificação se dá nos ramos e partes dos ramos que ainda não deram frutos, formados na estação anterior.

A planta de café, durante o ciclo, hospeda inúmeras espécies de organismos, alguns dos quais podem constituir em pragas e ou doenças importantes, afetando a produção e causando prejuízos aos cafeicultores.

Os fundamentos do manejo ecológico, com base na publicação do National Research Council (1996), pode ser estratificado em quatro princípios da natureza e da prática agrícola: $\left(1^{\mathrm{a}}\right)$ todos os organismos têm inimigos naturais, $\left(2^{\mathrm{a}}\right)$ todas as plantas toleram uma certa quantidade de infestação e ou infecção, $\left(3^{a}\right)$ todo controle pode ser seletivo e $\left(4^{\mathrm{a}}\right)$ todas as culturas podem ter equilíbrio (Gravena, 2003).

Com base no segundo princípio conclui-se que as plantas, inclusive o cafeeiro, apresentam mecanismos naturais de defesa e que a partir de determinado nível de infestação e ou infecção o agricultor deve interferir no sistema adotando práticas de manejo adequadas, considerando os aspectos econômicos e ambientais.

As plantas apresentam mecanismos que respondem de maneira diferente a um agente estressor, biótico ou abiótico, cuja natureza e intensidade da resposta variam com a idade, grau de adaptação e da atividade sazonal do vegetal (Oliveira, 2003). A defesa da planta deve ser 
entendida como um conjunto de processos que atuam associados, podendo-se admitir que raramente um único mecanismo explicaria a resistência e ou a suscetibilidade da planta (Oliveira \& Romeiro, 1991).

Os compostos fenólicos servem como defesa natural contra herbivoros e patógenos, tendo sido encontrada correlação entre os teores dessa substância com a resistência da planta (Misaghi, 1980; Goodman et al., 1986). Portanto, o nível de infestação e ou infecção vegetal podem ser atribuídas às diferenças nas concentrações desses compostos nas partes da planta.

Estudos efetuados sobre o assunto demonstraram que os aumentos dos compostos fenólicos nas plantas estão diretamente relacionados com a resistência à infestação e ou infecção de pragas e doenças, respectivamente. Entretanto, pouco se sabe sobre os niveis de fenóis durante os estádios fenológicos do cafeeiro, em particular, nas fases de frutificação, bem como em razão das variações climáticas ao longo do ciclo da planta. Tais conhecimentos são fundamentais para a previsão dos riscos de ataques dos organismos ao cafeeiro, servindo como uma ferramenta auxiliar para orientar o manejo das plantas.

Para o mecanismo de defesa natural as plantas desviam carboidratos da via metabólica principal utilizados na formação de grãos e crescimento vegetativo, para a via metabólica secundária visando, por exemplo, a produção de fenóis - substâncias protetivas. Pode-se admitir, por hipótese, que em anos de altas produções a demanda de carboidratos comprometerá a vegetação e a formação de substâncias que protegem as plantas das infestações e ou infecções, em razão da insuficiência de saldo de sacarose para o metabolismo secundário.

Do exposto, espera-se com esse trabalho acrescentar informações, além daquelas já estabelecidas pelas pesquisas, como o comportamento 
dos insetos ou patógenos em relação às condições climáticas, bem como sobre a influência do ambiente no ciclo reprodutivo desses organismos.

Esse trabalho foi realizado com o objetivo de avaliar o teor de fenóis totais nas folhas de cafeeiros durante o ciclo da planta nas fases de frutificação, em função da produção e das condições climáticas. A hipótese de trabalho se fundamenta na ocorrência de variações nos teores de fenóis, os quais podem ser correlacionados com os fatores do ambiente e a fenologia da planta, servindo como uma ferramenta auxiliar no manejo da cultura em relação aos fatores bióticos, durante o desenvolvimento do cafeeiro. Tais informações poderão ser de grande utilidade para a previsão do controle fitossanitário, utilizadas, por exemplo, em estações de alerta. 


\section{REVISÃO DE LITERATURA}

\subsection{Formação e função dos compostos fenólicos}

Os compostos fenólicos são metabólitos secundários produzidos pelas plantas sem apresentarem função direta no seu crescimento e desenvolvimento, porém são fundamentais para o metabolismo vegetal (Strack, 1997). Essas substâncias constituem um grupo quimicamente heterogêneo com várias funções nos organismos. Nem todos os fenóis têm função conhecida, sendo que alguns deles parecem ser simples intermediários do metabolismo das plantas (Beckman, 2000). A principal função relacionada aos compostos fenólicos está associada com a defesa do vegetal contra fatores externos, bióticos e abióticos, pois se trata de um mecanismo de resistência bioquímico pré-formado pela planta (Pascholati \& Leite, 1994).

As classes de compostos fenólicos mais importantes são: a lignina,

que fortalece mecanicamente as paredes celulares; os pigmentos flavonóides, que agem como uma proteção contra a radiação ultravioleta e como atrativos para os polinizadores e dispersores de sementes; os taninos, a lignina, os flavonóides e outros compostos fenólicos, atuam na defesa contra a herbivoria e os patógenos.

Segundo Getachew (1999) os taninos parecem ter um papel importante na proteção das plantas contra estresses ambientais, como a baixa fertilidade do solo e a deficiência hídrica.

Os compostos fenólicos são biossintetizados por meio de diferentes rotas - rota chiquímico e rota do ácido malônico, em células 
especializadas distribuídas pelos tecidos, ao acaso ou em locais estratégicos. As enzimas dessa síntese estão associadas ao retículo endoplasmático permitindo que, logo após a produção, esses compostos sejam armazenados em vesículas, na forma original ou glicolisada. A compartimentalização é fundamental para o funcionamento das células, pois os fenóis são tóxicos e devem ser mantidos na forma reduzida. A descompartimentalização dos fenóis pode levar à sua rápida oxidação pela ação das peroxidases, em resposta a infecção. Quando os fenóis se mantêm livres no citoplasma podem ser tóxicos aos patógenos como à própria célula vegetal, provocando reações de hipersensibilidade (Isaac, 1992; Hrazdina, 1994). Os taninos são encontrados, principalmente, nos vacúolos das plantas e, portanto, não interferem no metabolismo vegetal, exceto após a lesão ou morte das plantas quando se tornam eficientes na sua ação toxicológica (Cannas, 1999).

A fenilalanina é um importante intermediário na formação da maioria dos compostos fenólicos. A enzima responsável pela catalisação dessa etapa reguladora é a fenilalanina amonialiase (PAL), situada nas ramificações existentes entre os metabolismos primário e secundário. A atividade da PAL é aumentada por fatores ambientais tais como baixos niveis de nutrientes, intensidade luminosa, patógenos e insetos.

Segundo Rodrigues Junior (1980) os vegetais podem conter, em suas células, quantidades variáveis de compostos fenólicos que, em altas concentrações, ou quando oxidados de fenóis simples a quinonas e em radicais livres de fenóis, podem se constituir em barreiras microbianas.

Os compostos fenólicos são bem conhecidos como substâncias fungitóxicas, antibacterinas e antiviróticas (Friend, 1981). O efeito inibitório desses metabólitos na germinação dos esporos, crescimento micelial e produção de enzimas variam entre os diferentes grupos de 
fenóis. Dessa forma, essas substâncias têm sido consideradas como compostos que participam dos mecanismos de defesa das plantas.

O metabolismo primário e secundário do carbono é dependente da fotossintese e da formação de carboidratos. A partir do metabolismo primário, ocorre a biossíntese de compostos fenólicos por meio da realocação de fotoassimilados para o metabolismo secundário. Creasy (1968) verificou, em discos de folhas de morangueiro, a importância da fotossíntese e da produção de carboidrato na síntese de flavonóides, pigmentos que atuam na defesa natural das plantas e que controlam a biossintese de antocianina, substância atrativa aos polinizadores e dispersores de semente (metabolismo secundário).

A resistência das espécies vegetais aos insetos e patógenos, mediante o acúmulo de substâncias tóxicas se dá por meio dos compostos fenólicos, avaliados como uma alternativa à suscetibilidade dos vegetais (Kosuge, 1969).

Honner (1988) observou nos estádios fenológicos e durante um período de estresse ambiental que as plantas podem alterar a produção de taninos. Estudos em casa-de-vegetação evidenciaram que as plantas a pleno sol possuíam niveis de taninos duas a três vezes superiores às plantas que cresceram sob sombreamento (Coley, 1987). Do mesmo modo, Johnson et al. (1997) constataram que os niveis foliares de taninos e polifenóis em mudas de Fagus sylvatica foram elevados em plantas expostas ao sol, em comparação com aquelas desenvolvidas à sombra ou submetidas a meia sombra (exposição a 50 \% de luz).

A temperatura, aparentemente, influencia o teor de taninos, uma vez que durante o amadurecimento de bananas, armazenadas em temperaturas crescentes de $15^{\circ} \mathrm{C}$ a $35^{\circ} \mathrm{C}$, o conteúdo dessa substância diminuiu rapidamente com a elevação da temperatura (Esguerra et al., 1992). 
Durante o desenvolvimento vegetal também ocorrem mudanças nos níveis de taninos na planta. Lees et al. (1995) estudaram a alteração desses compostos em função da idade, mediante pesquisa histológica, e evidenciaram a sintese de taninos condensados nas camadas subepidérmicas no início do desenvolvimento foliar. Durante a fase de maturação não houve aumento dessa substância devido ao catabolismo desses metabólitos em folhas mais velhas e na fase de senescência. Hillis (1959) observou em Eucalyptus sieberiata F. Muell maior teor de polifenóis em folhas novas. Em Leucaena leucocephala também foram observados teores mais elevados de taninos em folhas jovens (Deotale et al., 1994). O mesmo ocorreu com os frutos de Psidium guajava, em que o conteúdo de taninos diminuiu com a maturação (Yusof et. al., 1998). Masoodi (1985), porém, obteve resultados diferentes em seus estudos com diversas espécies frutíferas, verificando que a concentração de taninos aumentava com a maturação das folhas.

Os compostos fenólicos podem estar envolvidos nos mecanismos bioquímicos e estruturais de resistência em plantas (Nicholson \& Hammerschmidt, 1992). Segundo Vidhysekaran (1988), diversas substâncias fenólicas estão associadas a resistências às doenças. Folhas de cevada inoculadas com Erysiphe graminis f. sp. hordei acumularam substâncias de natureza aromática, diferente da lignina, nos sítios de penetração do fungo (Mayama \& Shishiyama, 1978).

Bazzalo et al. (1985) trabalhando com plantas de girassol infectadas com Sclerotinia sclerotiorum encontraram um forte efeito inibitório do ácido isoclorogênico sobre o crescimento micelial do fungo, bem como elevados niveis de fenóis totais na região da lesão e ao redor dos tecidos em plantas tolerantes. Conti et al. (1986) observaram que um dos fatores de resistência de roseiras a Sphaerotheca pannasa é a capacidade dessas plantas sintetizarem grandes quantidades de 
compostos fenólicos. Bashan (1986) constatou que os compostos fenólicos extraídos de plântulas de algodão, infectadas com Alternaria macrospora, inibiram o crescimento do fungo in vitro, tendo constatado, também, que os teores de fenóis totais foram superiores nos materiais resistentes do que nos materiais suscetíveis.

\subsection{Resistência Induzida}

De maneira geral, as plantas não ficam passivas as agressões que sofrem de virus, viróides, fungos, bactérias (Bol et al., 1990) e insetos ou por agentes não-biológicos como a radiação solar, temperaturas extremas, poluição e outros. Todas as plantas possuem mecanismos de defesa, como a produção de compostos fenólicos, presença de cutícula, pêlos, etc.

A resistência induzida trata-se de uma manifestação temporária de proteção, em que a planta é mais suscetivel aos insetos e aos patógenos, devido ao estádio fenológico ou pela interação com as condições ambientais que podem, eventualmente, alterar a sua fisiologia. Concorrem para este fenômeno as variações na quantidade de água no solo (irrigação), nutrientes e outros. Cessadas estas condições o vegetal retoma a sua característica de planta suscetível. Esse tipo de resistência é caracterizado como resistência adquirida ou ecológica cuja expressão depende de fatores externos, morfológicos e, principalmente, químicos.

Em muitas espécies vegetais a resistência induzida se desenvolve a partir de ataques de insetos e ou patógenos, caracterizada pela redução no desempenho desses agentes em plantas atacadas, em relação às plantas que não sofreram qualquer tipo de dano por organismos. 
O fenômeno resultante da ativação de diferentes vias de defesa da planta, que provoca alterações na qualidade e quantidade de substâncias secundárias e nutritivas (ao agente agressor) denomina-se resistência induzida. Essa ativação é provocada por elicitores ou indutores podendo ser do tipo biótico e abiótico.

Os fatores bióticos constituem os insetos, fungos patogênicos, bactérias e plantas daninhas, enquanto como fatores abióticos podem ser enumerados a radiação solar, temperatura, umidade, os nutrientes, danos mecânicos e a ação fitotóxica dos defensivos agrícolas, mesmo daqueles recomendados às culturas.

O conhecimento dos mecanismos que interferem na defesa própria da planta ao ataque de pragas e doenças amplia a possibilidade de se obter um controle mais eficaz durante o manejo da cultura, bem como auxilia na previsão de ataques de organismos ao cafeeiro, servindo como uma ferramenta para orientar a ação do cafeicultor.

O mecanismo de resistência das plantas está associado com vários compostos, dentre eles estão os fenóis, que se destacam por serem amplamente distribuídos e por terem sido, até o momento, responsáveis pelo maior número de exemplos de resistência e recuperação a infecção por vários patógenos (Zuluaga et al., 1971).

Segundo Agrios (1997) as células e tecidos vegetais respondem aos danos ocasionados pelos patógenos mediante a uma série de reações bioquímicas, produzindo substâncias tóxicas em altas concentrações para inibir o desenvolvimento dos mesmos. Dentre essas substâncias estão incluídas a maioria dos compostos fenólicos, como os ácidos clorogênicos e cafeico, os produtos da oxidação dos compostos fenólicos e as fitoalexinas, que em sua maioria são também substâncias fenólicas. Nicholson \& Hammerschmidt (1992) afirmam que o acúmulo de fenóis em tecidos vegetais depende da interação hospedeiro-agressor, do nível 
de resistência do hospedeiro e, no caso de resistência induzida, do indutor.

Estudos realizados com diferentes interações hospedeiro inseto/patógeno, com cultivares resistentes e suscetíveis, evidenciaram que as plantas apresentaram maior teor de metabólitos secundários após o ataque. Trabalhos efetuados em cafeeiro demonstraram que as cultivares suscetiveis e resistentes aumentaram os niveis de fenóis após a inoculação do fungo, agente causal da ferrugem (Hemileia vastatrix), porém o teor e a velocidade desses aumentos foram diferenciados em razão das características das cultivares (Moraes et al., 1971).

De acordo com Farkas \& Kiraly (1962) as reações ocorridas nas variedades de trigo resistentes à ferrugem do colmo foram associadas com a acumulação rápida de compostos fenólicos, ao passo que nas variedades suscetiveis, apesar de ter havido aumento, o mesmo se deu lentamente.

Shimoni et al. (1991) estudando cultivares de milho resistentes à infecção por Exserohilum turcicum, mostraram que nas cultivares suscetiveis ocorreu um atraso na ativação do seu mecanismo de defesa, fazendo com que as plantas expressassem sintomas típicos da doença. Nesse aspecto, Kuc \& Pressig (1984) enfatizaram que a rapidez e a magnitude com que se dá a ativação dos mecanismos de defesa podem ser críticas para a expressão da resistência.

Resultados apresentados por Chaulfoun et al. (1995), no trabalho realizado com teores de fenóis em películas de bulbilhos de coloração normal e de coloração alterada em cultivares de alho, os autores evidenciaram que o conteúdo de fenóis totais variou de acordo com a cultivar embora, de maneira geral, este teor tenha sido mais elevado nos bulbilhos com a coloração das cascas alteradas, menos preferida pelos insetos. Nacacche (1983) também observou um aumento de fenóis totais 
em espécies suscetiveis e resistentes de café à ferrugem, sendo que nas espécies resistentes a produção de fenóis ocorreu de forma mais rápida e pronunciada.

As diferenças existentes entre as variedades suscetiveis e resistentes estão relacionadas com as variações nas concentrações de compostos fenólicos produzidos pelas plantas. Romanowski (1962) citado por Figueirêdo (1975) concluiu que tanto as variedades resistentes como as suscetiveis estão diretamente ligadas ao número de lesões existentes e que o aumento ou produção dos compostos fenólicos resulta da interação parasita/hospedeiro, uma vez que foram obtidas menores quantidades de compostos fenólicos em extratos de plantas sadias.

Figueirêdo (1975) estudando a interação entre feijoeiro e Fusarium solani observou que o fenol phaseollin é a principal substância envolvida na interação, encontrada em quantidades elevadas, tendo sido uma das primeiras detectadas no estudo. Observou, também, que as concentrações de compostos fenólicos totais em hipocótilos inoculados com Fusarium solani eram superiores em relação os hipocótilos não inoculados.

Pitta et al. (1990) trabalharam com diferentes progênies de seringueira submetidas à infecção por Microcylus ulei e avaliaram, comparativamente, o teor de compostos fenólicos totais produzidos pelas plantas. De acordo com os autores a resistência da seringueira à infecção por $M$. ulei parece estar associada à variação nos teores de fenóis totais em suas folhas. Observaram, também, que uma das progênies (H. pauciflora) apresentava elevado teor inicial de fenóis totais que aumentava após a inoculação do patógeno, o que, provavelmente, constitui uma vantagem para a defesa contra a colonização. 
Além dos fatores abióticos e bióticos que induzem certa resistência à planta a partir da síntese de compostos fenólicos, existem os fatores de redistribuição dessas substâncias na planta, bem como a idade do vegetal. Lee et al. citado por Oliveira \& Romeiro (1991) observaram em experimento com variedades de batatas uma alta resistência à murcha (Verticillium albo-atrum) e elevados teores de compostos fenólicos em plantas jovens pós-emergentes, os quais decresceram com o tempo e, conseqüentemente, diminuíram a resistência em plantas adultas.

O estado nutricional da planta está intimamente ligado com a biossintese de composto fenólicos, pois os nutrientes minerais participam de todas as fases do metabolismo das plantas e, portanto, a falta ou excesso desses nutrientes pode afetar processo. Os carboidratos provenientes do metabolismo primário da planta são precursores dos compostos fenólicos produzidos no metabolismo secundário e sua quantidade depende do acúmulo dessas substâncias pelas plantas (Amorim, 1970).

Os elementos minerais participam do metabolismo das plantas de diferentes formas; a deficiência de boro, por exemplo, segundo Watanabe et al. (1963) provocou um acúmulo de polifenóis em girassol. Amorin (1970) relatou que em plantas com baixo teor de nitrogênio e com maior concentração de glicose no meio afetaram, positivamente, a quantidade de compostos fenólicos produzida em cultura de tecido. São poucos os trabalhos tentando relacionar a nutrição da planta com a produção dessas substâncias, aspectos que deve ser considerados pelos pesquisadores.

Independentemente das interações hospedeiro - praga/patógeno existentes, os compostos fenólicos estão presentes e suas frações variam conforme a cultivar, a idade da planta, as condições ambientais em que as mesmas estão inseridas, o estado nutricional e a fenologia. 


\subsection{Fenologia do Cafeeiro}

O café é um arbusto de crescimento contínuo, com dimorfismo de ramos, caracterizado pela presença de ramo ortotrópico (tronco da planta), que cresce verticalmente, do qual originam os ramos plagiotrópicos (produtivos), que se desenvolvem lateralmente e inclinação variável com a cultivar, em relação ao ramo principal.

Os ramos plagiotrópicos se formam a partir de gemas diferencialmente determinadas (Carvalho et al., 1950). As gemas do caule que dão origem aos ramos produtivos são denominadas de gemas cabeça-de-série, ao passo que as gemas seriadas, eventualmente, se desenvolvem em ramos verticais ou ladrões, que crescem paralelamente a planta. Nas axilas das folhas dos ramos plagiotrópicos também existem gemas, as quais se diferenciam, conforme as condições do ambiente, em gemas reprodutivas. Nesses ramos, a gema mais desenvolvida da série (cabeça-de-série), em determinadas situações podem originar ramos plagiotrópicos de ordem superior.

O crescimento da parte aérea ocorre, praticamente, durante todo o período chuvoso, proporcionando o crescimento dos ramos por meio da emissão de folhas, em cujos nós se desenvolvem gemas, as quais após a diferenciação, determinarão a produção do ano seguinte, a altura do cafeeiro (emissão de novos ramos) e a espessura do caule.

O cafeeiro apresenta uma variação sazonal no crescimento vegetativo e reprodutivo, cujo padrão de periodicidade não se modifica. No entanto, o ritmo de crescimento das várias partes da planta difere, devido à interação entre os fatores genéticos, nutricionais, hormonais e ambientais (Taiz \& Zieger, 1991). É pouco conhecido os fatores que explicam a periodicidade de crescimento, incluindo entre os mesmos o fotoperíodo, a temperatura e a água (excesso ou déficite hídrico). 
Segundo Rena \& Maestri (1986) na região da Zona da Mata de Minas Gerais, o crescimento dos ramos é acelerado durante a estação quente e chuvosa e lenta na estação fria e seca.

O crescimento em altura das plantas e a extensão dos ramos laterais do cafeeiro são influenciados por elementos do clima como a intensidade solar, temperatura média anual e duração da temperatura máxima (Jaramillo \& Valência, 1980). O mesmo ocorre com o número de botões florais que são afetados por elementos climáticos. A oscilação da temperatura diurna e noturna pode ser benéfica (Mês, 1957). O autor verificou um maior número de botões florais por axila em cafeeiros cultivados sob temperaturas diurna/noturna de $23^{\circ} / 17^{\circ} \mathrm{C}$, enquanto que a $20^{\circ} / 17^{\circ} \mathrm{C}$ inibiu a iniciação floral.

O potencial de crescimento do meristema terminal da haste ortotrópica do cafeeiro reduz, acentuadamente, com a idade da planta, sendo que a altura final é uma característica da cultivar (Fazuoli, 1986).

O botão floral e as flores se desenvolvem com as primeiras chuvas na primavera, fases de intensa atividade fisiológica do cafeeiro, as quais dependem do desempenho da planta no inverno. Neste período, quando o padrão de crescimento da parte aérea é pequeno (outono/inverno), as raízes continuam funcionais (Amaral 1991), em razão do maior saldo de carboidratos, pois, o crescimento da parte aérea é menor sem haver, contudo, interrupção do processo fotossintético (Rena, 2000).

As variações sazonais no crescimento vegetativo são intensamente influenciadas pela presença de flores e frutos, ou seja, há competição dentro da planta pelos metabólicos disponiveis de acordo com os drenos.

Os períodos secos que antecedem a floração são importantes para o crescimento da raiz, para a maturação dos ramos formados na estação chuvosa precedente, para a diferenciação floral e a maturação dos frutos (Rena \& Maestri, 1986). 
A frutificação começa com o vingamento (ou pegamento) da flor e termina com a maturação do fruto. A polinização ocorre antes da antese assegurando uma elevada taxa de autofecundação para os cafeeiros da espécie Coffea arabica L.

A fenologia do cafeeiro foi esquematizada por Camargo \& Camargo (2001), tendo sido identificadas seis fases fenológicas distintas, duas vegetativas e quatro reprodutivas (Figura 1).

\begin{tabular}{|c|c|c|c|c|c|c|c|c|c|c|c|c|}
\hline \multirow{5}{*}{ Ano 1} & \multicolumn{12}{|c|}{ Periodo vegetativo } \\
\hline & \multicolumn{7}{|c|}{ Vegetação e formação das gemas foliares } & \multicolumn{5}{|c|}{$\begin{array}{l}\text { Indução e maturação das gemas } \\
\text { florais }\end{array}$} \\
\hline & Set & Out & Nov & Dez & Jan & Fev & Mar & Abr & Mai & Jun & Jul & Ago \\
\hline & & & & & & & & & & & & \\
\hline & & & & & & & & & & & \multicolumn{2}{|c|}{ Repouso } \\
\hline \multirow{6}{*}{ Ano 2} & \multicolumn{4}{|c|}{$\begin{array}{l}\text { Florada, chumbinho e } \\
\text { expansão dos frutos }\end{array}$} & \multicolumn{3}{|c|}{$\begin{array}{l}\text { Granação dos } \\
\text { frutos }\end{array}$} & \multicolumn{3}{|c|}{$\begin{array}{l}\text { Maturação dos } \\
\text { frutos }\end{array}$} & \multicolumn{2}{|c|}{$\begin{array}{c}\text { Repouso e } \\
\text { senescência } \\
\text { dos ramos } \\
\text { terciários e } \\
\text { quaternários }\end{array}$} \\
\hline & Set & Out & Nov & Dez & Jan & Fev & Mar & Abr & Mai & Jun & Jul & Ago \\
\hline & & & & & & & & & & & & \\
\hline & & & & & & & & & & & & \\
\hline & & & ríodo & reproc & ativo ( & ovo $\mathrm{p}$ & ríodo & egetat & & & Aut & oda \\
\hline & & & & & & dc & eprc & tivo & & & & \\
\hline
\end{tabular}

Figura 1 - Esquema das fases vegetativas e reprodutivas do cafeeiro arábica durante 24 meses (Adaptado de Camargo et al., 2001)

Da antese até a completa frutificação, com a formação do fruto verde, quando alcança o seu tamanho máximo, decorre um período de 4 a 6 meses, variável com a cultivar e a temperatura, enquanto a maturação demora, aproximadamente, 2 meses. A fase inicial é conhecida como "chumbinho", em que não há praticamente crescimento, e dura cerca de 6 semanas. 
Rena \& Maestri (1987) apontam em seu trabalho alguns fatores que afetam o crescimento do fruto. O tamanho final da cereja depende, acentuadamente, das chuvas entre a $10^{\mathrm{a}}$ e a $17^{\mathrm{a}}$ semanas após $\mathrm{o}$ florescimento, período que corresponde à fase de expansão rápida do fruto. Este fato pode ser explicado pela importância da água nos vacúolos celulares, exercendo pressão de turgor, indispensável a expansão das células.

Os cafeeiros com elevada carga pendente apresentam uma menor taxa de crescimento do que os cafeeiros sem fruto ou que ainda não tenham florescido, devido à alocação de fotoassimilados para a reprodução em detrimento do crescimento vegetativo.

A planta de café arábica apresenta como característica a bienalidade da produção, ou seja, após um ano de carga alta segue um ano de menor produção. A partição de carboidratos na planta é feita no sentido fonte - dreno. As flores e os frutos são drenos "fortes" e em ano de grande produção, as reservas de carboidratos (amido) e aqueles produzidos pela fotossintese corrente são, preferencialmente, alocados para o desenvolvimento dos mesmos (Cannell, 1985). Em anos de baixa produção, aparentemente, a competição é maior entre as partes vegetativas da planta.

Carvalho et al. (2001) trabalharam com diferentes níveis de produção de café (cultivar Mundo Novo), correlacionando os teores foliares de compostos fenólicos com a incidência de ferrugem. Os autores observaram que há maior predisposição das plantas à ferrugem em razão da presença da produção, promovendo, conseqüentemente, uma reação de defesa das plantas, pelo aumento da concentração dessa substância. Conclui-se, portanto, que o aumento da produção está correlacionado com o aumento da suscetibilidade do cafeeiro à ferrugem. Nestas condições, a planta aciona-se o mecanismo de defesa 
bioquímico, por intermédio do acúmulo de compostos fenólicos, que inibem o avanço temporário da doença.

A redistribuição dos nutrientes dentro da planta segue o mesmo princípio fonte - dreno. Durante o período de desenvolvimento e maturação dos frutos do cafeeiro, quando são alocadas grandes quantidades de nutrientes, diminui gradativamente as concentrações foliares, principalmente de macronutrientes, o que leva a acentuada queda de folhas (Bonnet, 1969). A ausência de folhas na cultura do cafeeiro provoca prejuizo na produção do ano seguinte.

Malavolta (1979) afirma que as concentrações de nutrientes das folhas variam conforme a produção, sendo, portanto, maiores em anos de grandes colheitas.

Os frutos em desenvolvimento mobilizam assimilados através da importação de carboidratos na fase de expansão rápida. Parte do carboidrato é utilizada para a formação de folhas e ramos novos e para retenção de frutos. A presença dos frutos estimula a fotossíntese, tanto que nos cafeeiros frutíferos é maior a quantidade de matéria seca do que naqueles sem frutos. Os próprios frutos em desenvolvimento (verdes), devido à presença de estômatos, podem sintetizar carboidratos, embora sua contribuição seja pequena.

O estádio fenológico do cafeeiro, principalmente durante a frutificação, influencia o teor de compostos fenólicos na planta, pois a produção abundante de frutos pode causar desequilíbrios nutricionais, tornando os cafeeiros suscetiveis às doenças e pragas. Durante as fases de maturação do grão de sorgo, Rodrigues et al. (1992) verificaram que a variação no teor de taninos estava associada com o menor ataque de pássaros. Os autores reportaram que, na fase de grão leitoso, o teor de taninos era elevado não observando nenhum dano, o que ocorreu somente a partir da fase de grão pastoso, estádio em que os materiais 
genéticos com alto teor de taninos não foram consumidos pelos pássaros.

A planta atende as demandas do crescimento vegetativo e reprodutivo mediante a partição dos fotoassimilados e pela redistribuição dos nutrientes.

Segundo Chaves \& Sarruge (1984) o acúmulo de matéria seca do fruto durante o seu desenvolvimento ocorre conforme apresentado na Figura 2.

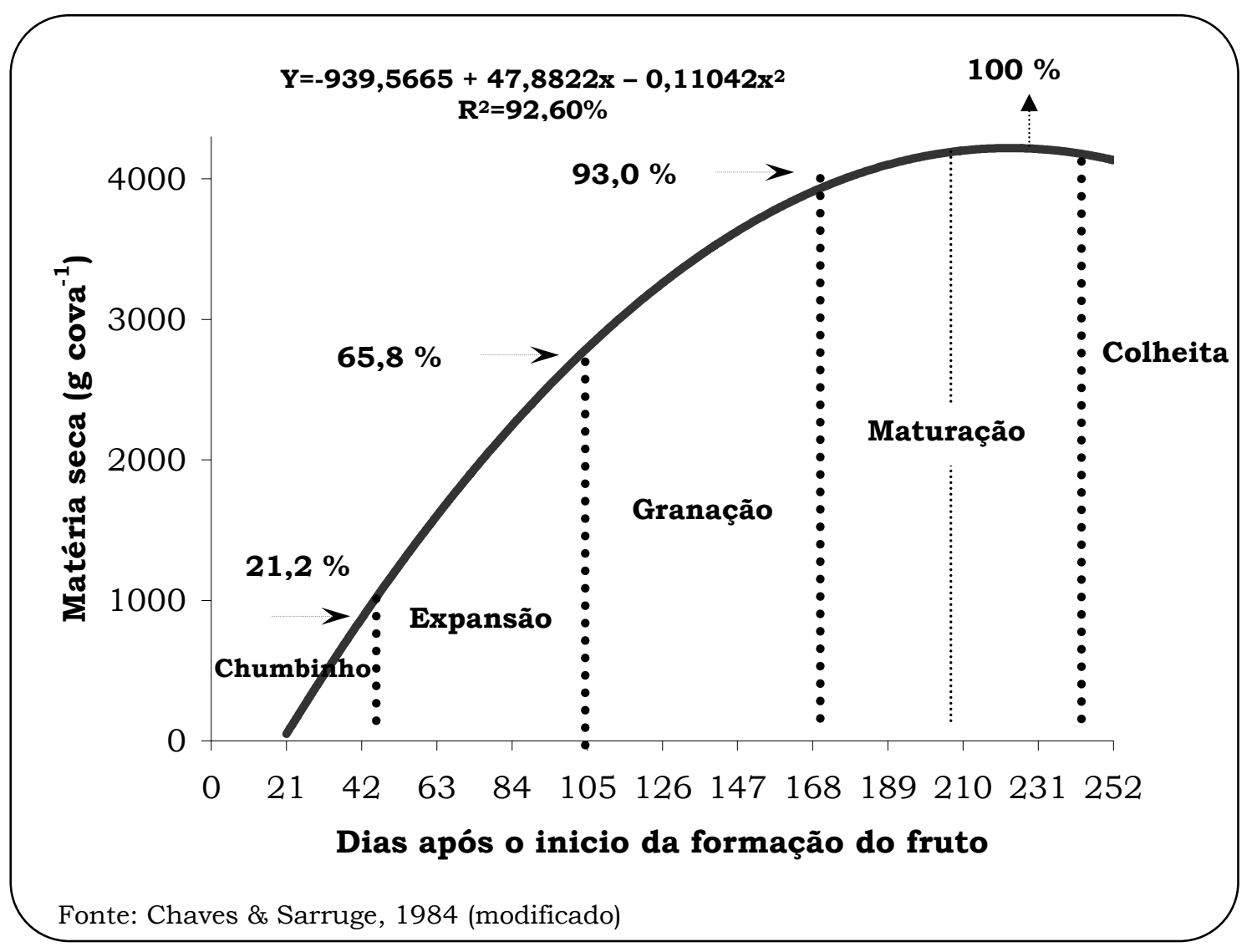

Figura 2 - Curva de regressão da quantidade de matéria seca (y: grama

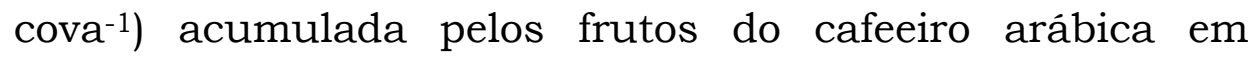
função do desenvolvimento (x: dias) 
A fase chumbinho, em que o crescimento do fruto não é visível, devido, provavelmente, ao predomínio de divisões celulares, apresentou um acúmulo de matéria seca igual a 21,2 \%, que ocorreu nos últimos 20 dias da referida fase. $\mathrm{Na}$ expansão rápida do fruto, ao fim da qual o endocarpo lignifica, o acúmulo de matéria seca é da ordem de 44,6 \% evidenciando elevada deposição de substâncias orgânicas nos frutos. $\mathrm{Na}$ fase de granação, em que há formação do endosperma a partir do final da expansão (endosperma leitoso), bem como na fase de maturação, caracterizada pelo endurecimento do endosperma e mudança da coloração da casca do fruto (epicarpo), os acúmulos de matéria seca são equivalentes a $27,2 \%$ e $5,8 \%$, respectivamente.

De acordo com comportamento evidenciado na Figura 2, o crescimento do fruto é contínuo e o ponto de maior acúmulo de matéria

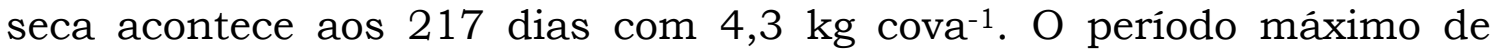
acumulação de matéria seca varia com a cultivar e as condições climáticas, principalmente a temperatura atmosférica (Chaves \& Sarruge, 1984). 


\section{MATERIAL E MÉTODOS}

\section{1 Área experimental e material genético}

O experimento foi realizado em uma cultura de café irrigada por gotejamento, da espécie Coffea arabica L. cv. Obatã IAC 1669-20, em formação, com quatro anos de idade. Entre as características dessa cultivar destacam-se a exigência em fertilidade, resistência a ferrugem (Hemileia vastatrix), maturação tardia e sua adaptação aos plantios adensados.

A cultura foi instalada no espaçamento de $3,40 \mathrm{~m} \times 0,90 \mathrm{~m}$, com uma densidade de 3.270 plantas por hectare, no campo experimental do Departamento de Produção Vegetal, da Escola Superior de Agricultura "Luiz de Queiroz", Universidade de São Paulo, Piracicaba, SP (Figura 3).
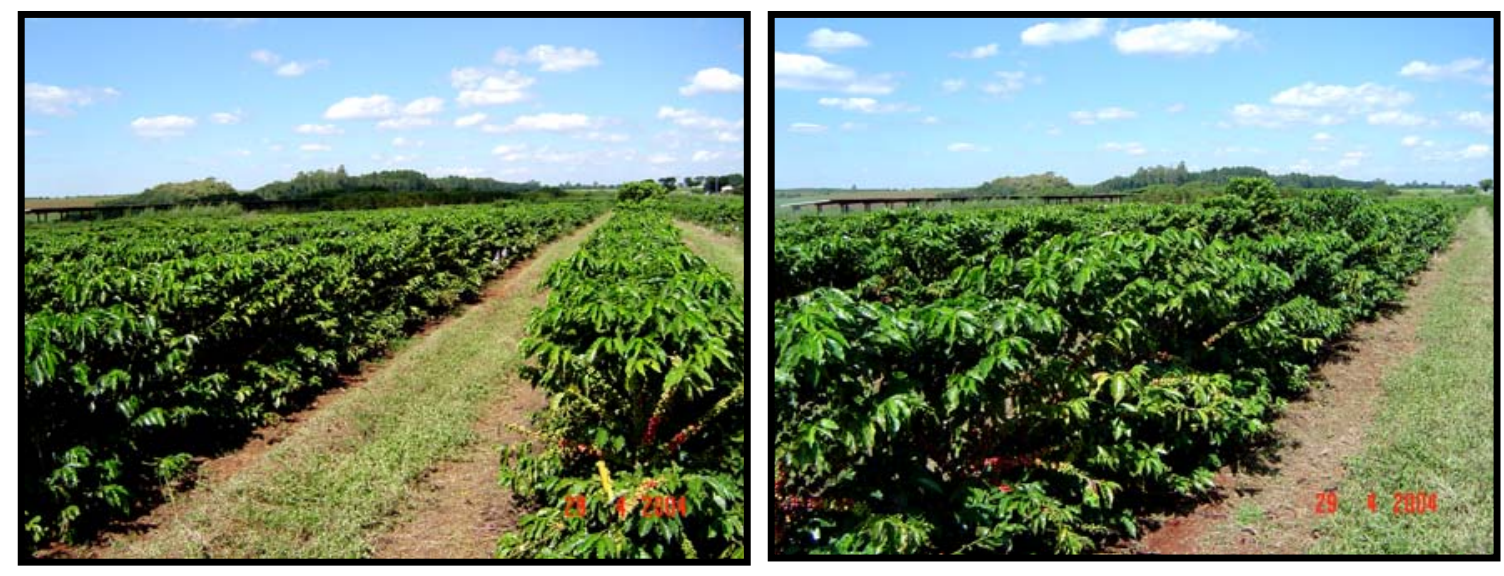

Figura 3 - Área experimental de café (cv. Obatã IAC 1669-20) da Escola Superior de Agricultura "Luiz de Queiroz", Universidade de São Paulo, Piracicaba, SP 
A área experimental está situada a 220 42' 30" de latitude Sul e 47 38' 00" de longitude Oeste e altitude média de $580 \mathrm{~m}$. De acordo com a classificação de Köppen o clima regional é do tipo Cwa, tropical de altitude com inverno seco.

\subsection{Manejo e condução das plantas}

O manejo e os tratos culturais foram realizados de acordo com as técnicas agronômicas preconizadas para a cultura do cafeeiro.

A adubação foi realizada com base na expectativa de produção de 30 sacas ha-1, cuja recomendação é de $240 \mathrm{~kg}$ de $\mathrm{N}, 40 \mathrm{~kg}$ de $\mathrm{P}_{2} \mathrm{O}_{5}$ e 160 $\mathrm{kg}$ de $\mathrm{K}_{2} \mathrm{O}$ por hectare, dividida em quatro parcelas (Raij et al., 1996).

No primeiro parcelamento, realizado em outubro de 2003, foi fornecido $25 \%$ da dose total de $\mathrm{N}\left(60 \mathrm{~kg} \mathrm{ha}^{-1}\right), 100 \%$ da dose de $\mathrm{P}_{2} \mathrm{O}_{5}$ (40 kg ha-1) e $50 \%$ da dose total de $\mathrm{K}_{2} \mathrm{O}\left(80 \mathrm{~kg} \mathrm{ha}^{-1}\right)$. No segundo parcelamento foi aplicado somente nitrogênio (25\% da dose), que equivale a $60 \mathrm{~kg} \mathrm{ha}^{-1}$, em novembro de 2003. A terceira aplicação foi efetuada em dezembro de 2003, tendo sido fornecido $25 \%$ de nitrogênio (60 kg ha-1) e $50 \%$ de $\mathrm{K}_{2} \mathrm{O}\left(80 \mathrm{~kg} \mathrm{ha}^{-1}\right)$. A adubação foi finalizada com a adição de $25 \%$ de nitrogênio (60 $\mathrm{kg} \mathrm{ha}^{-1}$ ) na quarta aplicação, em fevereiro de 2004. As fontes de nutrientes utilizadas na adubação do cafeeiro foram: sulfato de amônio $(18 \% \mathrm{~N})$, superfosfato simples (18\% $\left.\mathrm{P}_{2} \mathrm{O}_{5}\right)$ e cloreto de potássio $\left(60 \% \mathrm{~K}_{2} \mathrm{O}\right)$.

Para a avaliação do estado nutricional das plantas foi efetuada uma amostragem, em março de 2004, do terceiro par de folhas dos ramos localizados na parte mediana da planta representativa de cada repetição, cujos resultados são apresentados na Tabela 1. As semelhanças entre os teores de nutrientes evidenciam a uniformidade das plantas com e sem produção, aspecto fundamental para a comparação dos resultados experimentais. 
Tabela 1. Resultados da análise química foliar de macronutrientes em plantas de cafeeiro com e sem produção, em março de 2004

\begin{tabular}{|c|c|c|c|c|c|c|c|}
\hline Plantas & Repetições & $\mathrm{N}$ & $\mathrm{P}$ & $\begin{array}{l}\mathrm{K} \\
\mathrm{g} \mathrm{K}\end{array}$ & $\mathrm{Ca}$ & $\mathrm{Mg}$ & $\mathrm{S}$ \\
\hline \multirow{5}{*}{$\begin{array}{c}\text { Com } \\
\text { produção }\end{array}$} & Café 1 & 31,5 & 1,3 & 16,1 & 14,9 & 3,5 & 1,6 \\
\hline & Café 2 & 31,5 & 1,3 & 14,3 & 16,6 & 4,2 & 1,8 \\
\hline & Café 3 & 32,2 & 1,1 & 13,8 & 15,9 & 4,5 & 2,1 \\
\hline & Café 4 & 33,7 & 1,2 & 14,8 & 14,3 & 3,9 & 2,0 \\
\hline & Café 5 & 33,3 & 1,4 & 14,5 & 15,9 & 3,5 & 2,5 \\
\hline \multirow{7}{*}{$\begin{array}{c}\text { Sem } \\
\text { produção }\end{array}$} & Média & 32,4 & 1,3 & 14,7 & 15,5 & 3,9 & 2,0 \\
\hline & Café 1 & 36,1 & 1,4 & 13,8 & 12,4 & 3,6 & 2,2 \\
\hline & Café 2 & 35,0 & 1,4 & 14,8 & 10,4 & 3,2 & 1,7 \\
\hline & Café 3 & 35,7 & 1,4 & 13,5 & 11,6 & 3,4 & 1,7 \\
\hline & Café 4 & 38,3 & 1,6 & 14,5 & 10,8 & 3,2 & 1,8 \\
\hline & Café 5 & 37,2 & 1,6 & 15,0 & 11,0 & 3,1 & 1,9 \\
\hline & Média & 36,5 & 1,5 & 14,3 & 11,2 & 3,3 & 1,9 \\
\hline
\end{tabular}

As folhas para a análise química foram coletadas em plantas que ladeavam a planta marcada para o acompanhamento dos teores de fenóis. Esse procedimento foi adotado com o intuito de evitar o estresse proporcionado pela desfolha e, assim, não introduzir erros experimentais.

O extrato para a análise química do nitrogênio foi preparado por meio da digestão sulfúrica e nitro-perclórica para a determinação do fósforo, potássio, cálcio, magnésio e enxofre. $O$ nitrogênio foi determinado pelo método Micro Kjeldahl, o fósforo por calorimetria do metavanadato, o potássio por fotometria de chama de emissão e o cálcio e o magnésio por espectrofotometria de absorção atômica. A determinação do enxofre foi realizada por turbidimetria do sulfato de bário (Sarruge \& Haag, 1974; Bataglia et al., 1983). 
As pragas e as doenças foram controladas, preventivamente, por meio da aplicação, no solo, de defensivos sistêmicos usando aldicarb (temik, 10 g planta $^{-1}$ ) em setembro de 2003 e a mistura de dissulfoton associado com triadimenol (baysiston, $15 \mathrm{~g}^{\text {planta-1) }}{ }^{-1}$ em novembro de 2003 e janeiro de 2004. O controle preventivo foi efetuado para evitar a ocorrência desses organismos, os quais poderiam influenciar a produção de fenóis, afetando os resultados experimentais.

As plantas avaliadas, assim como a cultura, foram irrigadas durante todo o ciclo, utilizando sistema de gotejamento, com a finalidade de impedir que as plantas sofressem estresse hídrico. Esse cuidado foi necessário para desconsiderar esse fator abiótico (água) nas correlações entre o teor de fenóis totais com as variáveis climáticas preditoras.

\subsection{Avaliação dos teores de fenóis totais}

Os teores de fenóis totais foram determinados nas folhas dreno (primeiro par de folhas) e folhas fonte (terceiro par de folhas) dos ramos plagiotrópicos voltados para as entrelinhas e localizados na porção mediana das plantas Figura 4. 

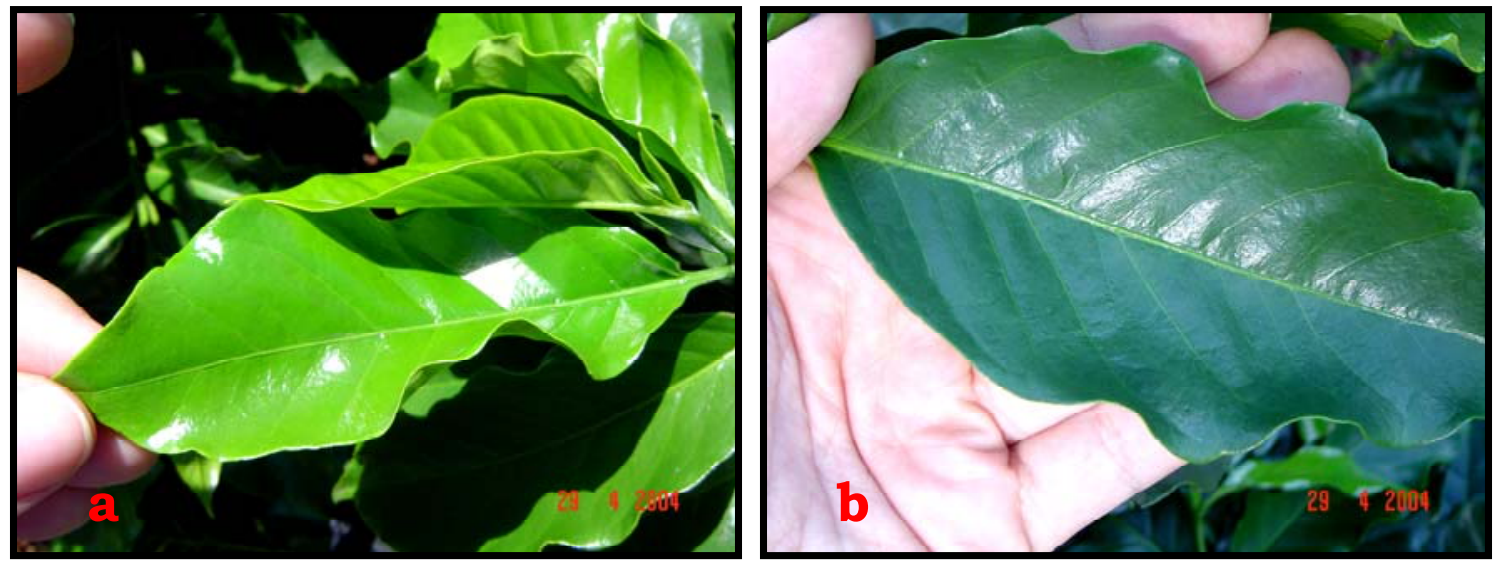

Figura 4 - Folhas dreno (a) e folhas fonte (b) amostradas nas fases de frutificação para a análise dos teores de fenóis totais

As folhas dreno (Figura 4 a) são folhas novas recém expandidas, com coloração verde clara e textura lisa em relação às folhas fontes, as quais são folhas maduras, com coloração verde mais intensa e textura áspera (Figura 4 b).

As coletas foram efetuadas em plantas com carga pendente e plantas sem frutos, das quais foram retirados as flores e os frutos no início do desenvolvimento (fase "chumbinho"). As amostragens de materiais (folhas) foram realizadas no mesmo período, sempre pela manhã, para não influenciar os resultados finais. Após as coletas, as folhas foram colocadas em sacos de papel e levadas, em seguida, para o laboratório, onde foram acondicionadas em câmara fria.

Durante as fases de frutificação do cafeeiro foram realizadas seis coletas de folhas (fonte e dreno) de ramos com e sem frutos nas seguintes épocas: (i) fase "chumbinho" (22/11/2003); (ii) expansão (18/12/2003), (iii) granação $(05 / 03 / 2004)$, (iv) início da maturação (19/05/2004), (v) final da maturação (12/07/2004) e (vi) florescimento (07/10/2004). 
As análises foliares de fenóis totais foram feitas no Laboratório do Centro de Energia Nuclear na Agricultura - CENA, Universidade de São Paulo. A determinação de fenóis totais foi efetuada de acordo com o seguinte procedimento: adicionou $50 \mu 1$ do extrato de folhas em tubos de ensaio contendo $450 \mu \mathrm{l}$ de água destilada, $250 \mu \mathrm{l}$ do reagente Folin Ciocalteu (1 N) diluído (1:1) e 1,25 $\mathrm{ml}$ de carbonato de sódio (20\%). Os tubos de ensaio com o extrato para análise foram agitados e, após 40 minutos, procedeu-se às leituras em espectrofotômetro, medindo a absorbância a $725 \mathrm{~nm}$. Para a obtenção dos resultados de fenóis totais ( $\mu \mathrm{g} \mathrm{g}^{-1}$ ) utilizou-se como padrão o ácido tânico.

\subsection{Avaliação do crescimento vegetativo}

Durante a condução do experimento foram realizadas avaliações do crescimento vegetativo das mesmas plantas amostradas para as análises dos teores de fenóis totais. Esse procedimento foi realizado com o objetivo de estimar, indiretamente, a alocação de carboidratos nas plantas com produção e sem produção de frutos de café.

Nessa avaliação complementar foram determinadas as taxas de crescimento das plantas em diâmetro (TCD), em altura (TCH) e em

comprimento de ramos plagiotrópicos (TCR), a partir do acompanhamento da altura da planta $(\mathrm{cm})$, diâmetro do caule $(\mathrm{mm})$, e comprimento dos ramos plagiotrópicos $(\mathrm{cm})$.

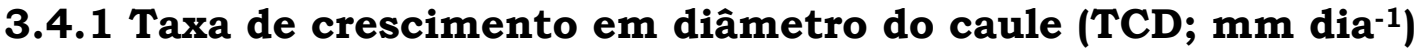

Essa variável foi determinada por meio das medidas de diâmetro do caule ( $\mathrm{DC}, \mathrm{mm})$, efetuada com paquímetro digital, na região localizada abaixo da cicatriz de inserção das folhas cotiledonares. 
A taxa de crescimento do diâmetro (TCD) foi calculada de acordo com a expressão 1 :

$$
\mathrm{TCD}=\Delta \mathrm{DC} / \Delta \mathrm{t}
$$

em que TCD ( $\left.\mathrm{mm} \mathrm{dia}^{-1}\right)$ corresponde à taxa de crescimento do diâmetro das plantas, $\triangle \mathrm{DC}(\mathrm{mm})$ a variação do diâmetro obtido em cada intervalo de amostragem e $\Delta \mathrm{t}$ (dia) aos intervalos entre as amostragens (t2-t1; t3t2; t4-t3; t5-t4; t6-t5 e t7-t6).

\subsubsection{Taxa de crescimento em altura da planta (TCH; $\mathbf{~ c m ~ d i a - 1 ) ~}$}

Para a determinação da altura $(\mathrm{H}, \mathrm{cm})$ foi efetuada a medida com régua milimetrada entre o nível do solo, na região do colo da planta e a inserção do último par de folhas expandidas.

A taxa de crescimento em altura (TCH) foi calculada de acordo com a expressão 2:

$$
\mathrm{TCH}=\Delta \mathrm{H} / \Delta \mathrm{t}
$$

em que TCH $\left(\mathrm{cm} \mathrm{dia}^{-1}\right)$ corresponde à taxa de crescimento em altura das plantas, $\Delta \mathrm{H}(\mathrm{cm})$ a variação da altura obtida em cada intervalo de amostragem e $\Delta \mathrm{t}$ (dia) aos intervalos entre as amostragens (t2-t1; t3-t2; t4-t3; t5-t4; t6-t5 e t7-t6).

\subsubsection{Taxa de crescimento de ramos plagiotrópicos (TCR; cm dia-1)}

Os ramos marcados, aleatoriamente, foram identificados e colocados em determinados nós uma fita indicativa. Todas as medidas de comprimento foram feitas sempre a partir do ponto previamente identificado (fita). 
A taxa de crescimento dos ramos plagiotrópicos (TCR) foi calculada de acordo com a expressão 3:

$$
\mathrm{TCR}=\Delta \mathrm{CR} / \Delta \mathrm{t}
$$

em que TCR $\left(\mathrm{cm} \mathrm{dia}^{-1}\right)$ corresponde à taxa de crescimento dos ramos plagiotrópicos identificados, $\Delta \mathrm{CR}(\mathrm{cm})$ a variação do comprimento desses ramos em cada intervalo de amostragem e $\Delta$ t (dia) aos intervalos entre as amostragens (t2-t1; t3-t2; t4-t3; t5-t4; t6-t5 e t7-t6).

As avaliações complementares (DC, $\mathrm{H}$ e CR) foram feitas nas mesmas épocas e nas mesmas plantas nas quais foram coletadas as amostras de folhas para a análise química de fenóis totais.

\subsection{Dados climatológicos}

Para avaliar a influência do clima sobre a formação de fenóis totais, foram adotadas as seguintes variáveis preditoras: radiação global $\left(\mathrm{MJ} \mathrm{m}^{-}\right.$ $2 \mathrm{dia}^{-1}$ ), insolação diária (horas $\mathrm{dia}^{-1}$ ) e a temperatura diária (média, máxima e minima, $\left.{ }^{\circ} \mathrm{C}\right)$.

Esses dados foram obtidos no posto Meteorológico da Escola Superior de Agricultura "Luiz de Queiroz", Universidade de São Paulo, localizado a, aproximadamente, $100 \mathrm{~m}$ da área experimental.

Para correlacionar os teores de fenóis totais com as variáveis climáticas preditoras foram utilizados os valores médios dos teores de fenóis correspondentes a cada fase da frutificação do cafeeiro.

$\mathrm{Na}$ fase 'chumbinho' as amostras foram coletadas em 21 de novembro de 2003 e o período utilizado para obtenção das médias das variáveis climatológicas foi entre 11 de outubro a 21 de novembro de 2003. Para a fase de expansão (18/dez/2004) utilizou-se o período de 22 de novembro a 18 de dezembro de 2003, enquanto para a granação 
(05/março/2004) o período de 1 de fevereiro a 5 de março de 2004. Para a fase inicial (19/abril/2004) e final da maturação (12/jul/2004) foram utilizados os periodos de 1 de abril a 19 de maio e 1 de junho a 12 de julho de 2004, respectivamente. O teor de fenóis totais no florescimento (07/out/2004) foi realizado no periodo de 1 de setembro a 7 de outubro de 2004. Esses períodos foram definidos a partir do dia, mês e ano em que ocorreram as coletas das amostras para as análises de fenóis.

\subsection{Delineamento experimental}

Para a realização do experimento foi adotado o delineamento experimental inteiramente casualizado, utilizando quatro tratamentos e cinco repetições constituídas por plantas individuais. Essas plantas foram identificadas aleatoriamente no campo e marcadas para que o acompanhamento do crescimento e a determinação dos teores de fenóis fossem realizados nas mesmas plantas, fundamental para permitir a comparação dos resultados.

Após a análise de variância foi aplicado o teste $t$ de Student ao nível de $5 \%$ de significância para a comparação das médias dos tratamentos. $\mathrm{O}$ teste $\mathrm{t}$ se fundamenta na hipótese da nulidade (Ho: $\mu_{1}=$ $\mu_{2}$ ), formulada com o objetivo de rejeitá-la, e na hipótese alternativa (H1: $\mu_{1} \neq \mu_{2}$ ). Quando os resultados obtidos em uma amostra diferem dos resultados esperados, com suporte na teoria das probabilidades, conclui-se que as diferenças observadas são significativas e rejeita-se a hipótese da nulidade em favor da hipótese alternativa, ou seja, que os tratamentos diferem entre si (Banzatto \& Kronka, 1992). 


\section{RESULTADOS E DISCUSSÃO}

\subsection{Produção de fenóis nas plantas}

O experimento foi conduzido de forma que o cafeeiro não sofresse estresse hídrico, nutricional, por ataque de pragas e doenças e por infestação de plantas daninhas. Nesse contexto, pode-se admitir por hipótese que o metabolismo de defesa do vegetal não seria acionado e, conseqüentemente, o nível de compostos fenólicos oscilaria, conforme as demandas por carboidratos em razão das fases de frutificação e crescimento vegetativo variáveis com as condições climáticas.

De acordo com os resultados das análises foliares de fenóis totais não existe evidência estatística $(a=0,05)$ para rejeitar a hipótese da nulidade, de que o valor médio de fenóis totais nas folhas dreno das plantas com e sem produção sejam iguais $\left(\mathrm{t}_{\mathrm{obs}}=-1,6533 ; \mathrm{p}\right.$-valor $=$ 0,1042), conforme visualizado na Figura 5. 


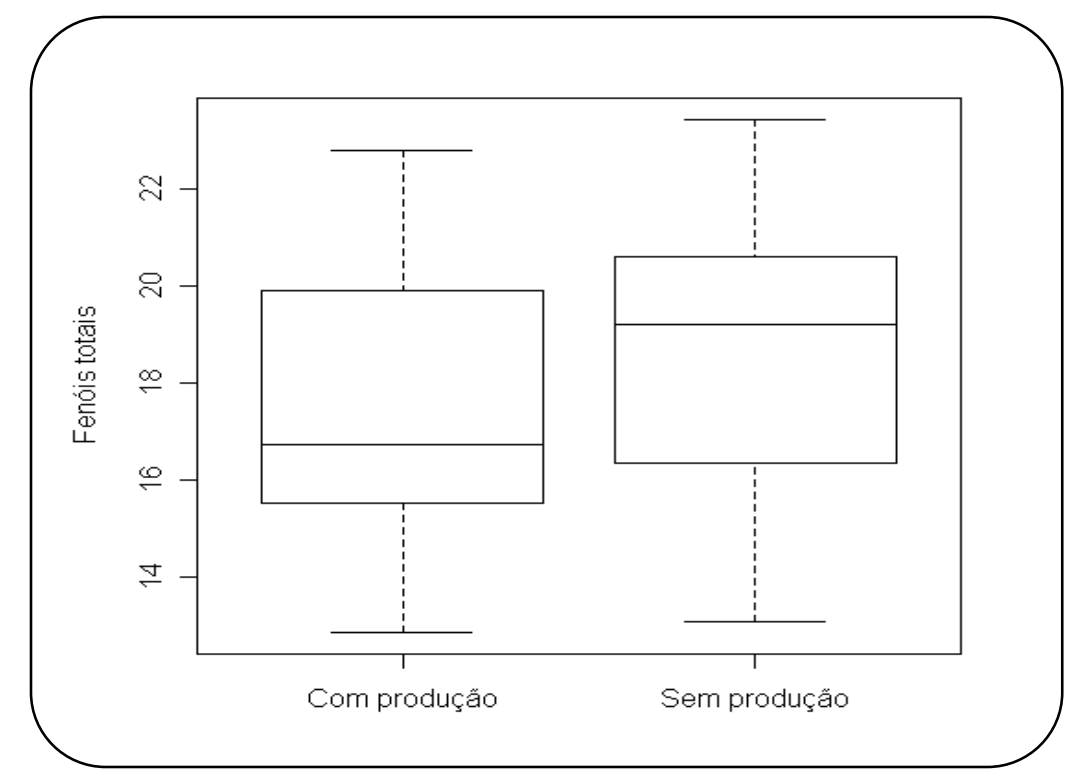

Figura 5 - Teores de fenóis totais $\left(\mu \mathrm{g} \mathrm{g}^{-1}\right)$ nas folhas dreno das plantas com e sem produção de café

As folhas dreno das plantas sem produção de café (Figura 5) apresentaram tendência de sintetizar maiores quantidades de fenóis totais em relação às folhas dreno das plantas com produção de café. Essa tendência se deve, provavelmente, a ausência do dreno principal os frutos, havendo assim um maior saldo de carboidrato que poderia ser alocado para a produção de compostos secundários - os fenóis.

Resultados semelhantes foram verificados nas folhas fontes, não havendo evidência estatística $(a=0,05)$ para rejeitar a hipótese da nulidade, de que o valor médio de fenóis totais nas folhas fonte das plantas com e sem produção sejam iguais $\left(\mathrm{t}_{\mathrm{obs}}=0,4608 ; \mathrm{p}\right.$-valor $=$ 0,6469) (Figura 6). 


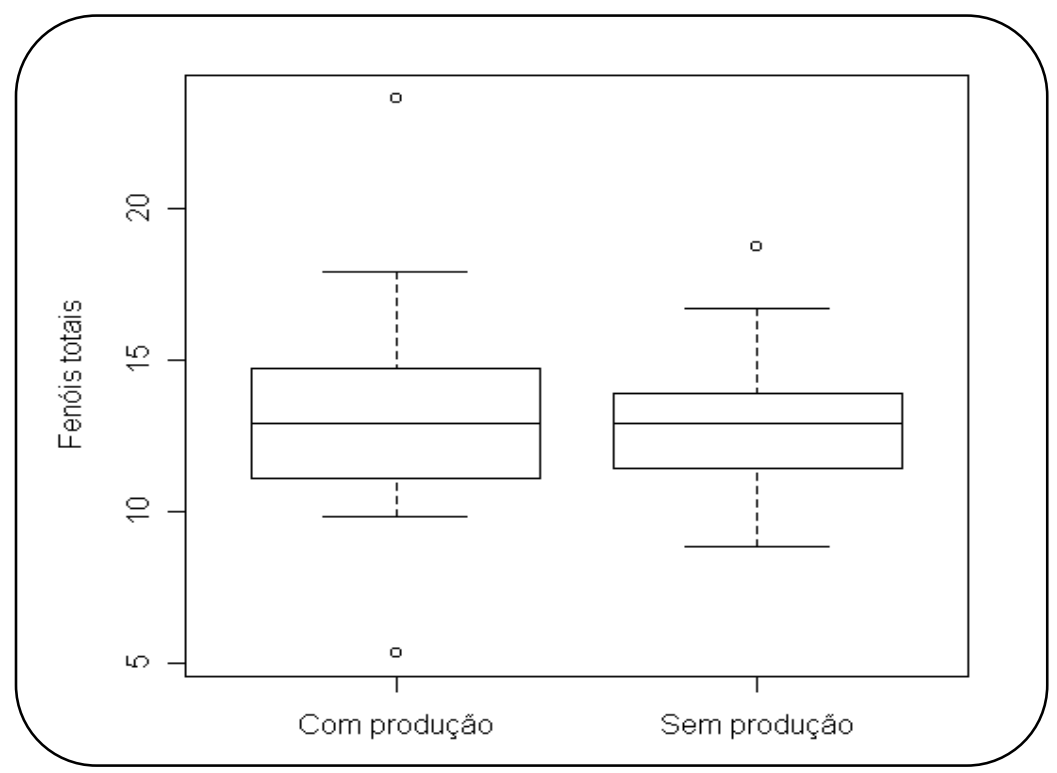

Figura 6 - Teores de fenóis totais $\left(\mu \mathrm{g} \mathrm{g}^{-1}\right)$ nas folhas fonte das plantas com e sem produção de café

As médias dos teores de fenóis totais das folhas dreno das plantas com produção $\left(17,40 \mu \mathrm{g} \mathrm{g}^{-1}\right)$ e sem produção $\left(18,65 \mu \mathrm{g} \mathrm{g}^{-1}\right)$ de café podem ser visualizadas na Figura 7 , bem como as médias de fenóis totais nas folhas fonte com $\left(13,89 \mu \mathrm{g} \mathrm{g}^{-1}\right)$ e sem frutos $\left(12,76 \mu \mathrm{g} \mathrm{g}^{-1}\right)$. 


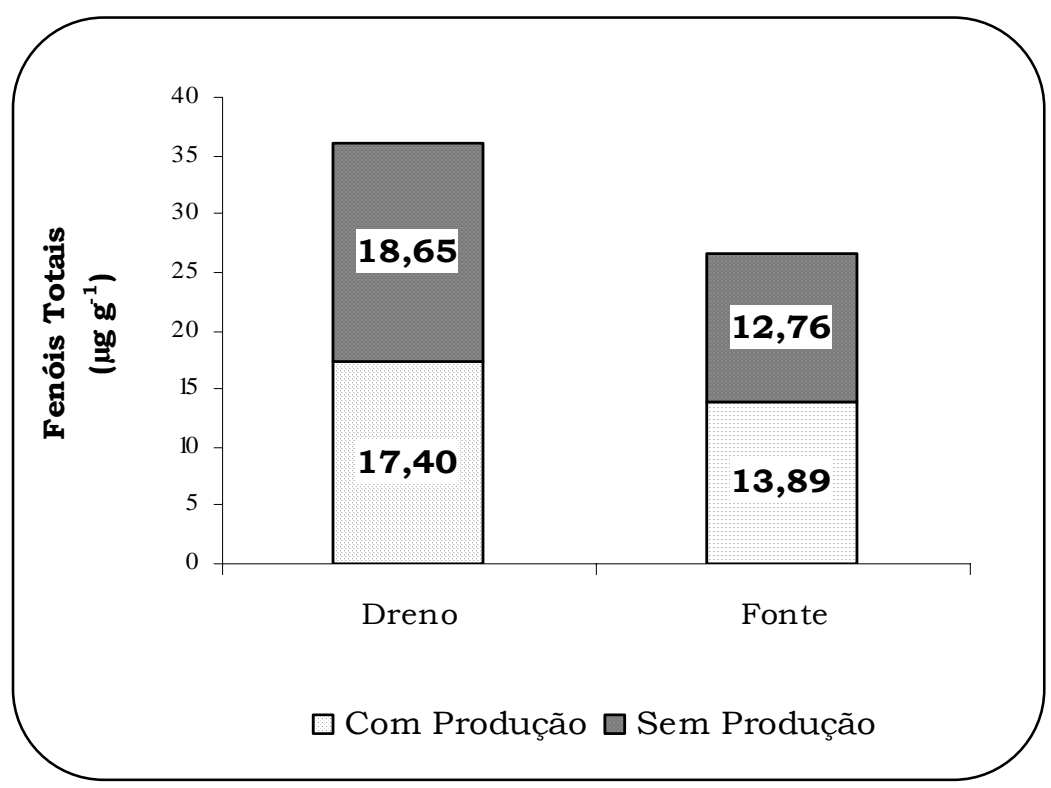

Figura 7 - Teores médios de fenóis totais $\left(\mu \mathrm{g} \mathrm{g}^{-1}\right)$ nas folhas dreno e fonte das plantas com e sem produção de café

A sintese de metabólitos secundários não é, exclusivamente, dependente do saldo de carboidrato que não foi alocado aos frutos, uma vez que não há diferença estatística entre as plantas com e sem produção de café. Tal afirmação se deve ao fato de que, no presente experimento, as plantas estão em formação (4 anos) e, portanto, na ausência de produção pode-se esperar maior dispêndio de carboidrato com o crescimento vegetativo das plantas.

As concentrações de fenóis totais não variam significativamente com a produção de café beneficiado (Figura 8). Entretanto, observa-se a tendência de existir uma relação inversa entre a produção e a formação dessa substância, ou seja, as plantas (1 e 3) com produção média de 40 sacas ha ${ }^{-1}$ tenderam a sintetizar mais fenóis (média de $16,0 \mu \mathrm{g} \mathrm{g}^{-1}$ ). O contrário foi evidenciado nas plantas 2 e 4 com produção média de 43 sacas ha-1, enquanto o teor médio de fenóis totais foi da ordem de 14,2 
$\mu \mathrm{g} \mathrm{g}^{-1}$. Isso se deve, possivelmente, a partição de carboidratos entre o metabolismo primário e secundário. Assim, a síntese de substâncias secundárias (fenóis) dependeria do saldo de sacarose, proporcionando, dessa maneira, maior probabilidade de proteção às plantas.

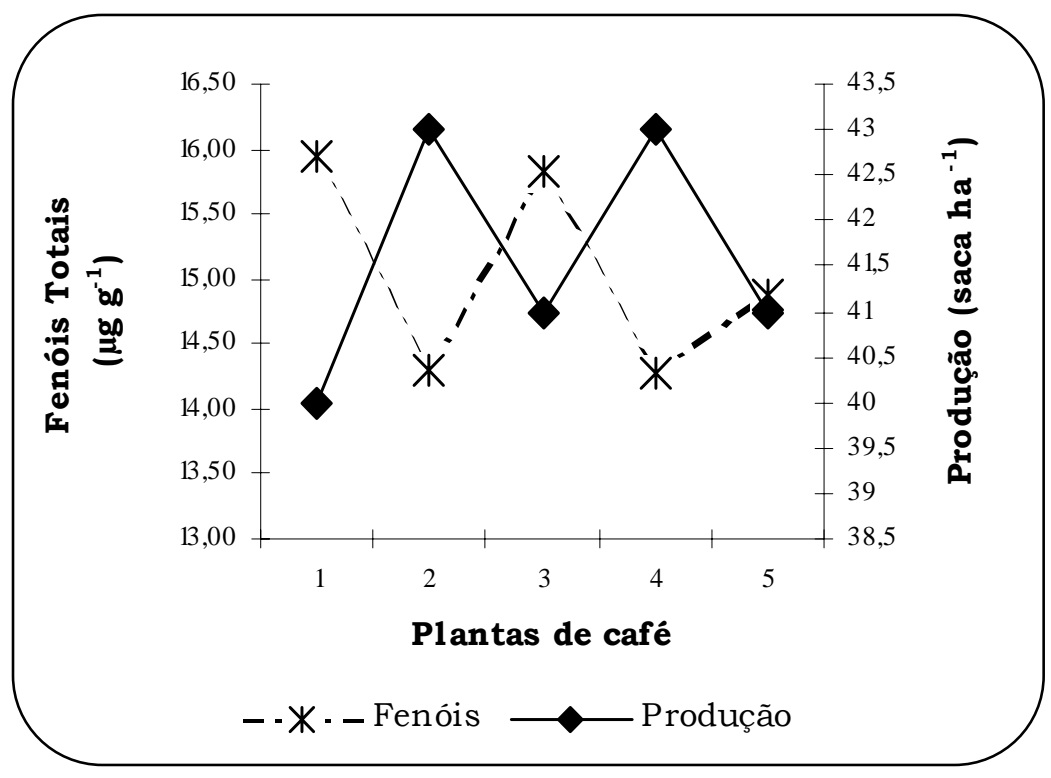

Figura 8 - Teores de fenóis totais $\left(\mu g \mathrm{~g}^{-1}\right.$ ) nas plantas em razão da produção de café beneficiado (sacas ha-1)

\subsubsection{Folhas dreno e fonte}

A distribuição e a localização dos fenóis nas plantas não são conhecidas claramente. Entretanto, é sabido que as quantidades variam de acordo com os órgãos, a idade, o estádio de desenvolvimento das plantas e as condições climáticas.

Conforme visualizada na Figura 9, não existe evidência estatística $(a=0,05)$ para aceitar a hipótese da nulidade, de que a produção média de fenóis totais nas folhas fonte e dreno das plantas com produção de café sejam iguais ( $\mathrm{t}_{\mathrm{obs}}=5,3366 ; \mathrm{p}$-valor $\left.1,924 \mathrm{e}^{-6}\right)$. 


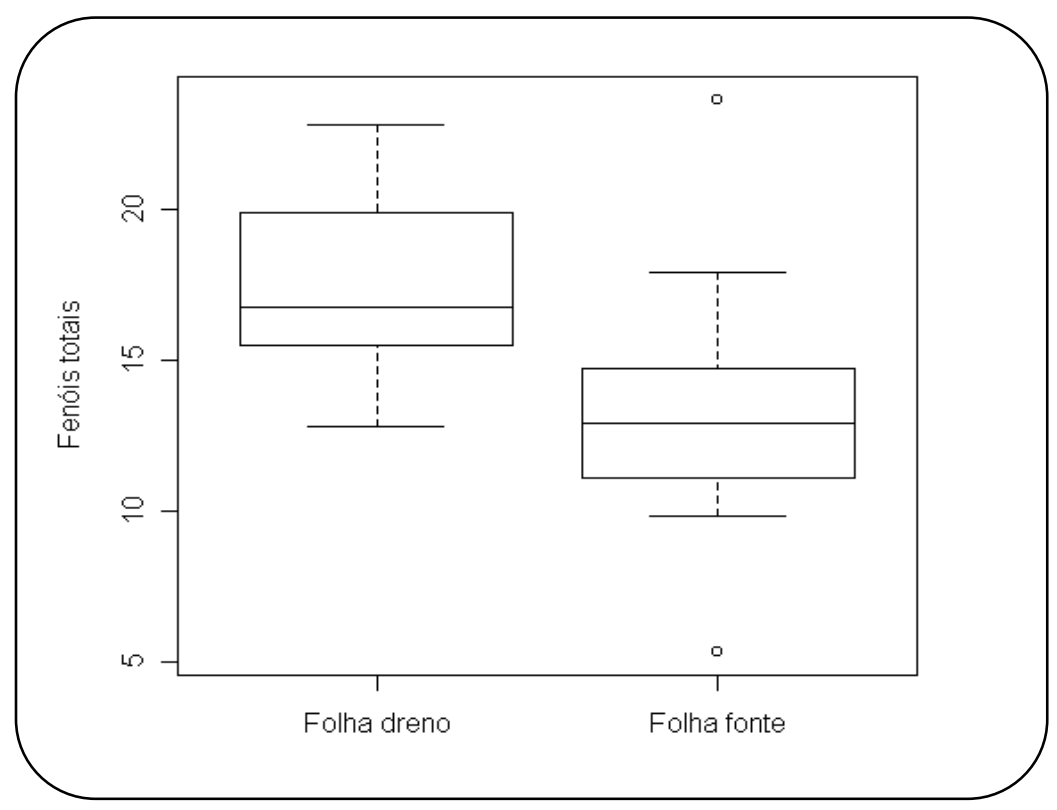

Figura 9 - Teores de fenóis totais $\left(\mu \mathrm{g} \mathrm{g}^{-1}\right)$ nas folhas dreno e fonte das plantas com produção de café

As concentrações de fenóis totais entre as folhas dreno e fonte das plantas sem produção apresentaram diferença estatística. $\mathrm{O}$ valor de $\mathrm{t}$ observado pelo teste de Student, aplicado nesses resultados, foi igual a 8,935 e o p-valor igual a $1,974 \mathrm{e}^{-12}$, afirmando que há diferença significativa a $5 \%$ de probabilidade entre os tratamentos (Figura 10). 


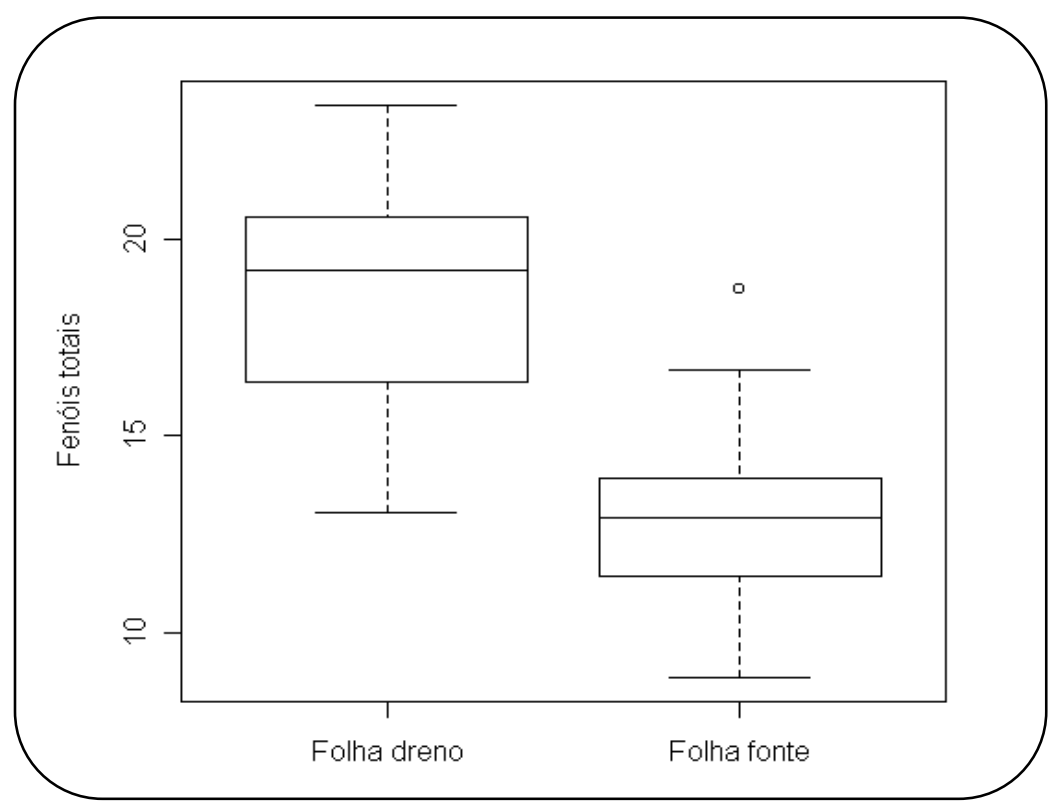

Figura 10 - Teores de fenóis totais $\left(\mu \mathrm{g} \mathrm{g}^{-1}\right)$ nas folhas dreno e fonte das plantas sem produção de café

A sintese de fenóis totais nas folhas dreno das plantas com $(17,40$ $\left.\mu \mathrm{g} \mathrm{g}^{-1}\right)$ e sem produção de café $\left(18,65 \mu \mathrm{g} \mathrm{g}^{-1}\right)$ foi maior que a quantidade determinada nas folhas fonte $\left(13,89 \mu \mathrm{g} \mathrm{g}^{-1}\right.$ e $\left.12,76 \mu \mathrm{g} \mathrm{g}^{-1}\right)$, da ordem de $25 \%$ e $46 \%$, respectivamente. Esses resultados corroboram as observações de Oliveira (1991), que verificou em seu trabalho maior concentração de fenóis nas folhas novas em relação às folhas velhas.

As folhas novas, depois dos frutos, são drenos preferenciais e, portanto, os nutrientes e os carboidratos são desviados para o desenvolvimento das mesmas. Comportamento semelhante pode ocorrer com os metabólitos secundários que, também, são realocados para a proteção desses órgãos. Uma hipótese para explicar esse resultado está relacionada com a morfologia dessas folhas (novas), uma vez que as mesmas são mais suscetiveis aos fatores externos, devido a pouca lignificação, processo que aumenta com a maturidade. O período que 
antecede a maturação foliar é o mais vulnerável aos fatores bióticos e abióticos sendo, provavelmente, necessária a translocação de fotoassimilados para o metabolismo secundário nessas folhas (dreno). A maior quantidade de fenóis nas folhas fonte pode ser explicado pela redistribuição de fenóis das folhas maduras (fonte) para folhas novas (dreno). Esse resultado corrobora aqueles obtidos por Hillis (1959) em estudos com Eucalyptus sieberiata e com Leucaena leucocephala em trabalho realizado por Deotale et al. (1994).

\subsubsection{Fases de frutificação}

A frutificação do cafeeiro pode ser dividida em seis fases distintas: florescimento (E6); fruto em "chumbinho" (E1), fruto em expansão (E2); fruto em granação (E3); fruto em maturação inicial (E4) e em maturação final (E5).

As Tabelas 2 e 3 reúnem os valores de $t$ observado (valor estatístico que será comparado com o valor crítico de t) associados aos periodos equivalentes às fases de frutificação (E1-E2; E2-E3; E3-E4; E4E5; E5-E6) e os teores médios de fenóis totais nas folhas dreno e fonte das plantas sem produção de café. Para aceitar a hipótese da nulidade, de que as médias entre os tratamentos sejam iguais, os valores de $\mathrm{t}$ observados devem estar no intervalo entre $-2,5<\mathrm{t}_{\text {obs }}<2,5$, ao nível de $5 \%$ de significância pelo teste de Student. 
Tabela 2. Teores médios de fenóis totais $\left(\mu \mathrm{g} \mathrm{g}^{-1}\right)$ nas folhas dreno das plantas sem produção, valores de t observados e hipótese da nulidade nos períodos das fases de frutificação do café

\begin{tabular}{lccc}
\hline $\begin{array}{c}\text { FASES DA } \\
\text { FRUTIFICAÇÃo }\end{array}$ & $\begin{array}{c}\text { FENÓIS TOTAIS } \\
\text { (Médias; } \boldsymbol{\mu g} \mathbf{~ g - 1 )}\end{array}$ & $\mathbf{t}$ obs & $\begin{array}{c}\text { HIPÓTESE DA } \\
\text { NULIDADE }\end{array}$ \\
\hline E1 - E2 & $\mathbf{2 0 , 4 9 - \mathbf { 1 6 , 3 5 }}$ & $\mathbf{3 , 5 9 6}$ & Rejeita \\
E2 - E3 & $16,35-14,68$ & 1,910 & Aceita \\
E3 - E4 & $\mathbf{1 4 , 6 8 - 2 0 , 0 8}$ & $\mathbf{- 7 , 0 8 7}$ & Rejeita \\
E4 - E5 & $20,08-21,24$ & $-1,024$ & Aceita \\
E5 - E6 & $21,24-19,18$ & 1,934 & Aceita \\
\hline
\end{tabular}

$\mathrm{Na}$ fase fenológica equivalente a E1 (frutos em "chumbinho"), as folhas dreno das plantas de café sem produção (Tabela 2) sintetizaram uma quantidade de compostos fenólicos $\left(20,49 \mu \mathrm{g} \mathrm{g}^{-1}\right)$, aproximadamente, $25 \%$ superior à quantidade determinada na fase equivalente a E2 (fruto em expansão; 16,35 $\mu \mathrm{g} \mathrm{g}$-1). Na fase equivalente a E3 (frutos em granação) apresentou uma produção de fenóis totais $\left(14,68 \mu \mathrm{g} \mathrm{g}^{-1}\right)$ inferior àquela determinada fase equivalente a $\mathrm{E} 4$ (início da maturação; 20,08 $\mu \mathrm{g} \mathrm{g}^{-1}$ ), da ordem de $27 \%$.

Os periodos equivalentes às fases de frutificação que apresentaram diferença nos teores médios de fenóis totais nas folhas fontes das plantas sem produção (E1-E2 e E3-E4; Tabela 2) foram os mesmos verificados nas folhas fontes, conforme visualizado na Tabela 3. 
Tabela 3. Teores médios de fenóis totais ( $\mu \mathrm{g} \mathrm{g}^{-1}$ ) nas folhas fonte das plantas sem produção, valores de t observados e hipótese da nulidade nos períodos das fases de frutificação do café

\begin{tabular}{|c|c|c|c|}
\hline $\begin{array}{c}\text { FASES DA } \\
\text { FRUTIFICAÇÃO }\end{array}$ & $\begin{array}{l}\text { FENÓIS TOTAIS } \\
\text { (Médias; } \mu \mathrm{g} \mathrm{g}^{-1} \text { ) }\end{array}$ & $t$ obs & $\begin{array}{c}\text { HIPÓTESE DA } \\
\text { NULIDADE }\end{array}$ \\
\hline E1 - E2 & $14,72-11,79$ & 2,377 & Rejeita \\
\hline $\mathrm{E} 2-\mathrm{E} 3$ & $11,79-10,63$ & 1,552 & Aceita \\
\hline E3 - E4 & $10,63-13,40$ & $-5,991$ & Rejeita \\
\hline E4 - E5 & $13,40-12,15$ & 0,955 & Aceita \\
\hline E5 - E6 & $12,15-13,87$ & $-1,126$ & Aceita \\
\hline
\end{tabular}

$\mathrm{Na}$ fase fenológica equivalente a E1 (frutos em "chumbinho"), as folhas fonte das plantas sem produção de café (Tabela 3) sintetizaram maior quantidade de compostos fenólicos (14,72 $\left.\mu \mathrm{g} \mathrm{g}^{-1}\right)$, aproximadamente, $25 \%$ superior à quantidade determinada na fase equivalente a E2 (fruto em expansão; 11,79 $\mathrm{g} \mathrm{g} \mathrm{g}^{-1}$ ). Na fase equivalente a E3 (frutos em granação) apresentou uma produção de fenóis totais $\left(10,63 \mu \mathrm{g} \mathrm{g}^{-1}\right)$ inferior a fase equivalente a E4 (início da maturação; 13,40 $\mu \mathrm{g} \mathrm{g}^{-1}$ ), da ordem de $21 \%$.

Os resultados apresentados no item 4.1 (Figuras 5 e 6), indicam que as plantas com e sem fruto sintetizaram quantidades semelhantes de fenóis totais. Portanto, essas plantas tiveram o mesmo comportamento em relação a metabolização de fenóis durante as fases de frutificação. Entretanto, a discussão foi feita com base nos resultados obtidos para as plantas sem produção, por isso, foi utilizado o termo equivalente para a identificação das fases reprodutivas. A opção para a discussão dos resultados de fenóis totais das plantas sem produção se deve à perda de dados na fase da maturação final e no florescimento das plantas com produção. 
Nas Figuras 11 e 12 pode-se observar a variação dos teores de compostos fenólicos nas folhas dreno e fonte ao longo das fases fenológicas equivalente à frutificação, em cafeeiros sem produção de fruto.

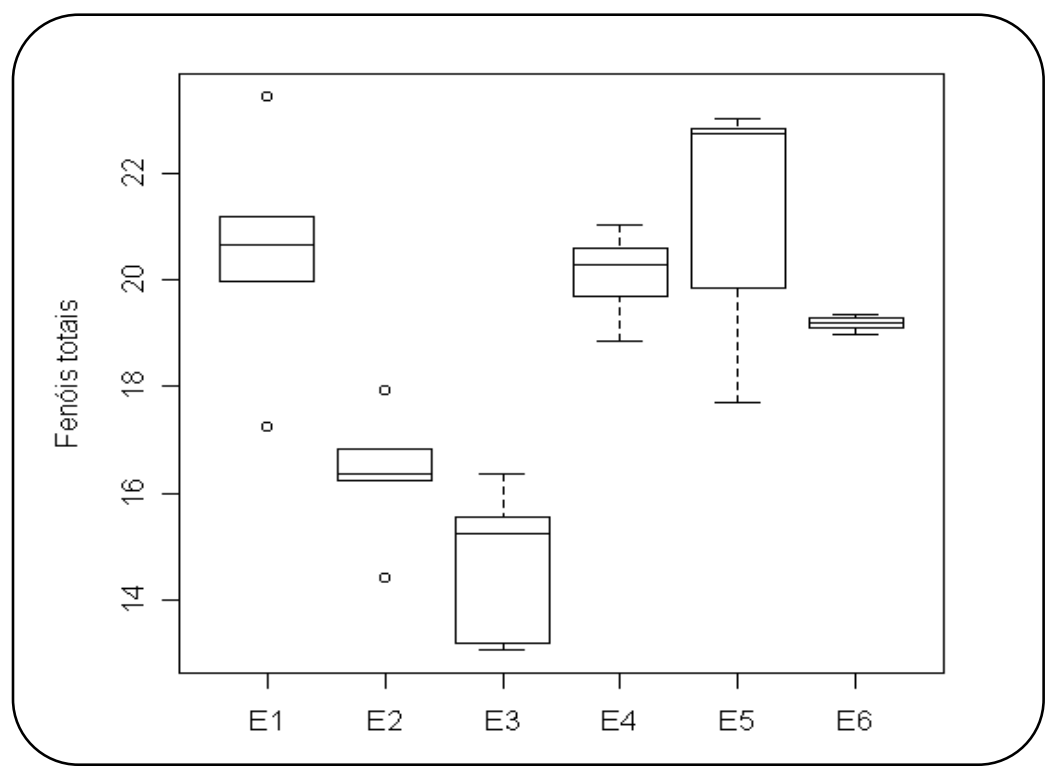

Figura 11 - Teores de fenóis totais $\left(\mu \mathrm{g} \mathrm{g}^{-1}\right)$ nas folhas dreno das plantas sem produção de café nos períodos equivalentes as fases de frutificação

De acordo com os resultados apresentados na Figura 11, verificase que nas fases equivalentes a E2 (frutos em expansão) e a E3 (frutos em granação; $14,68 \mu \mathrm{g} \mathrm{g}^{-1}$ ) as folhas dreno produziram menores teores de substâncias secundárias, aproximadamente, 31 \% inferior em relação à fase de maior sintese de fenóis totais - equivalente à fase E5 (frutos em final da maturação; $\left.21,24 \mu \mathrm{g} \mathrm{g}^{-1}\right)$.

O comportamento da sintese de fenóis totais nas folhas fonte de plantas sem produção de frutos ao longo das fases equivalentes a 
frutificação foi semelhante às folhas dreno, conforme evidenciados na Figura 12. Essa observação pode ser comprovada pelos resultados apontados nas Tabelas 2 e 3 . Do exposto, não serão discutidos os resultados obtidos para fenóis nas folhas fonte das plantas sem produção.

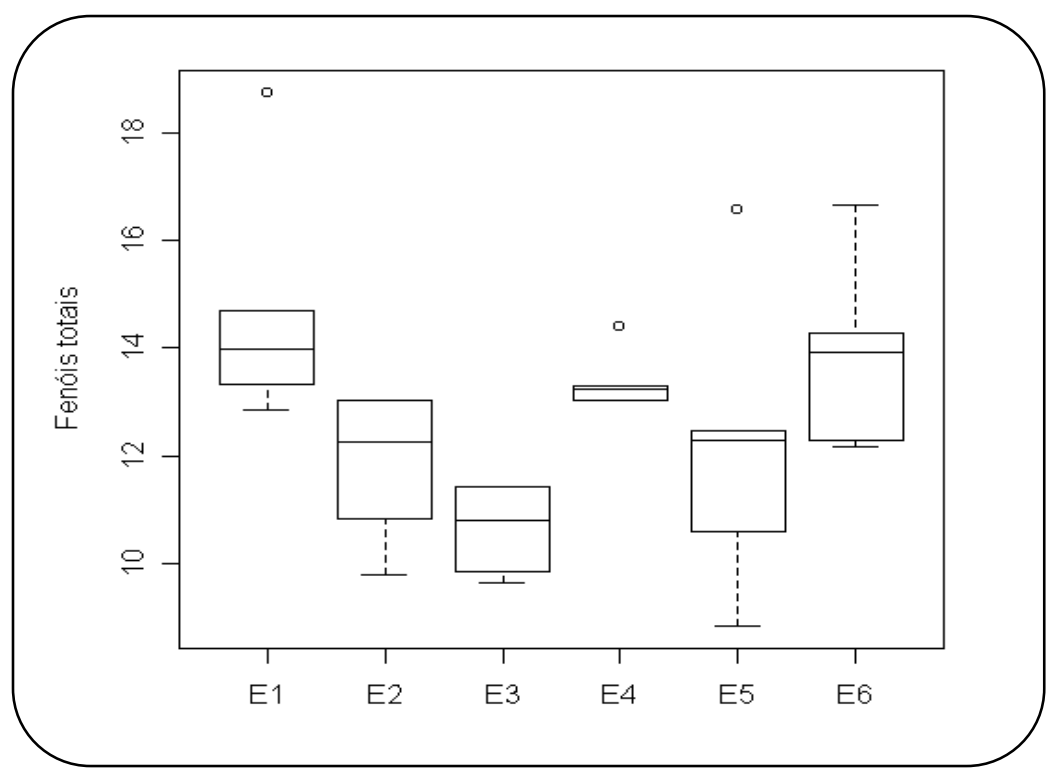

Figura 12 - Teores de fenóis totais $\left(\mu \mathrm{g} \mathrm{g}^{-1}\right)$ nas folhas fonte das plantas sem produção de café nos períodos equivalentes as fases de frutificação

O cafeeiro com elevada produção de frutos demanda grandes quantidades de fotoassimilados nas fases de expansão e granação, para o crescimento e desenvolvimento dos frutos e, conseqüentemente, maior acúmulo de matéria seca, conforme constatado por Chaves e Sarruge (1984). Nesses períodos da frutificação, o nivel de carboidrato disponível para o metabolismo secundário diminui, aumentando, provavelmente, a suscetibilidade das plantas aos ataques de organismos. Portanto, as 
fases E2 (fruto em expansão) e E3 (fruto em granação), equivalente ao período de dezembro a janeiro no presente trabalho, as plantas com produção apresentaram a menor quantidade de substâncias protetivas compostos fenólicos.

No período em que não há crescimento visivel dos frutos, o qual corresponde à fase "chumbinho", o acúmulo de matéria seca é mínimo, da ordem de 21,2\%, que equivale a $900 \mathrm{~g} \mathrm{cova}^{-1}$ (Chaves \& Sarruge, 1984) (Figura 2). Nessa fase fenológica o teor médio de fenóis totais é superior àquele determinado no estádio de expansão, fase de crescimento rápido dos frutos.

$\mathrm{O}$ acúmulo de matéria seca nos frutos em fase de maturação é da ordem de 5,8 \% $\left(4,2 \mathrm{Kg} \operatorname{cova}^{-1}\right)$, representando uma diminuição acentuada em relação às fases anteriores (Figura 2). Nesta fase ocorrem apenas reações químicas relacionadas com a maturação físiológica do fruto, sendo assim o teor médio de fenóis totais é superior à quantidade determinada na fase de granação, em que há formação do endosperma.

Nas Figuras 13 e 14 pode ser evidenciada a diferença significativa de crescimento vegetativo $(p<0,05)$ para a TCD e a TCR entre as plantas com e sem produção de frutos, nos períodos entre as fases fenológicas E1-E2 (frutos em "chumbinho" e em expansão) e E3-E4 (frutos em granação e em início de maturação).

Nas plantas que foi evitado artificialmente a presença de frutos, a diminuição de fenóis totais se deve, provavelmente, ao fato de que, no presente experimento, essas plantas se encontravam em fase de formação - crescimento vegetativo. Nessas condições (sem produção), a demanda de carboidrato para a vegetação explica a queda na síntese de fenóis totais (Figuras 13 e 14).

As plantas sem produção de café metabolizaram, também, menores teores de fenóis nas fases E2 e E3 (Tabelas 2 e 3), devido a 
maior taxa de crescimento do diâmetro do caule (TCD) e do comprimento dos ramos plagiotrópicos (TCR) nos períodos E1-E2 e E3E4 da frutificação, justificando a afirmação anterior. Na ausência de frutos (dreno preferencial) os fotoassimilados foram deslocados para o crescimento dos órgãos vegetativos (espessura do caule e comprimento dos ramos produtivos) nas respectivas plantas.
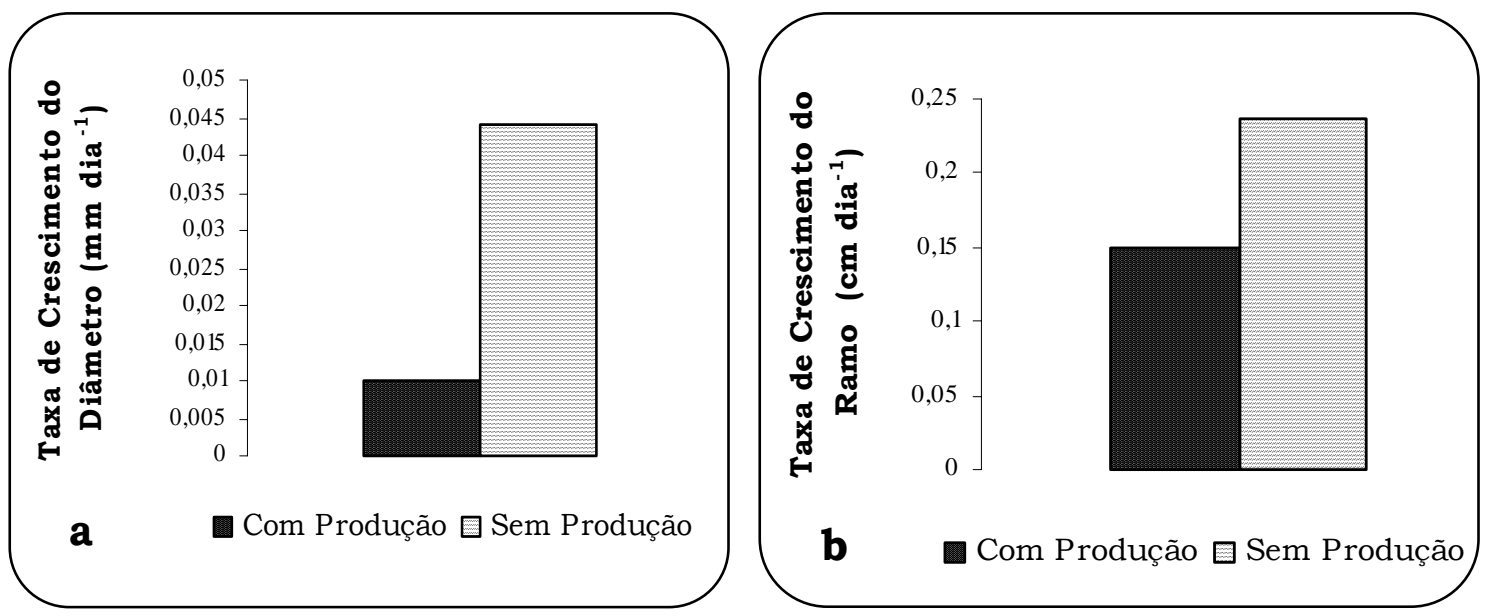

Figura 13 - Taxa de crescimento do diâmetro (TCD; $\mathrm{mm}$ dia-1) (a) e taxa de crescimento do comprimento dos ramos plagiotrópicos (TCR; cm dia-1) (b) das plantas com e sem produção de café, no período entre as fases fenológicas E1-E2 (frutos em chumbinho e em expansão)

A taxa de crescimento em diâmetro das plantas sem produção de frutos $\left(0,044 \mathrm{~mm} \mathrm{dia}^{-1}\right)$, no período entre E1-E2 (Figura $\left.13 \mathrm{a}\right)$, foi da ordem de 4,5 vezes superior às plantas com frutos $\left(0,0098 \mathrm{~mm} \mathrm{dia}^{-1}\right)$. Em relação à taxa de crescimento dos ramos plagiotrópicos (Figura 13 b) as plantas sem produção tiveram maiores taxas de crescimento $(0,24 \mathrm{~cm}$ 
dia $\left.^{-1}\right)$ em relação às plantas com produção $\left(0,15 \mathrm{~cm} \mathrm{dia}^{-1}\right)$, da ordem de $60 \%$.
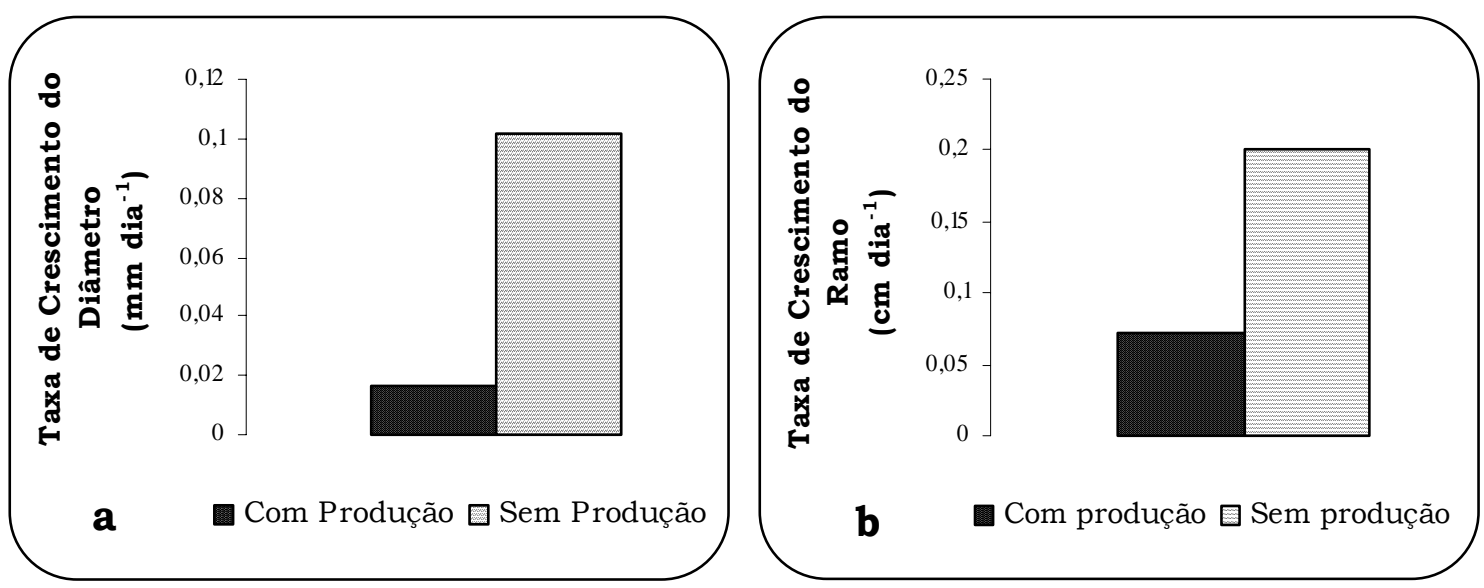

Figura 14 - Taxa de crescimento do diâmetro (TCD; $m m$ dia $^{-1}$ ) (a) e taxa de crescimento do comprimento dos ramos plagiotrópicos (TCR; cm dia ${ }^{-1}$ ) (b) das plantas com e sem produção de frutos, no período entre as fases fenológicas E3-E4 (frutos em granação e em início da maturação)

A taxa de crescimento em diâmetro das plantas sem frutos $(0,10$ $\mathrm{mm}$ dia $^{-1}$ ) no período entre E3-E4 foi 5,9 vezes superior às plantas com produção $\left(0,017 \mathrm{~mm} \mathrm{dia}{ }^{-1}\right)$ (Figura 14 a). Resultado semelhante foi verificado para a taxa de crescimento dos ramos plagiotrópicos, em que as plantas sem produção apresentaram valores maiores $\left(0,20 \mathrm{~cm} \mathrm{dia}^{-1}\right)$, da ordem de 2,85 vezes em relação a taxa de crescimento das plantas com produção $\left(0,07 \mathrm{~cm} \mathrm{dia}^{-1}\right)$ (Figura $\left.14 \mathrm{~b}\right)$.

Nos períodos entre as fases fenológicas E1 - E2 e E3 - E4 (Figura 15) a taxa de crescimento em altura das plantas ( $\mathrm{TCH}$; $\mathrm{cm}$ dia $^{-1}$ ) não apresentaram diferença estatística ao nível de $5 \%$ de significância entre as plantas com e sem produção de café. Embora não tenha diferido 
estatisticamente observa-se que entre as fases de frutos em granação (E3) e início da maturação (E4), período de grande demanda por carboidrato, a taxa de crescimento em altura nas plantas com produção foi igual a $0,00093 \mathrm{~cm} \mathrm{dia}^{-1}$, enquanto nas plantas sem produção a mesma foi, em média, igual a 0,00104 $\mathrm{cm} \mathrm{dia}^{-1}$ (Figura $15 \mathrm{~b}$ ). Os valores médios da taxa de crescimento entre as fases E1-E2 (frutos em chumbinho e em expansão; Figura 15 a), quando a demanda por carboidrato é menor em relação às fases E3-E4 (frutos em granação e em início da maturação; Figura 15 b), verifica-se maiores taxas de crescimento em altura.
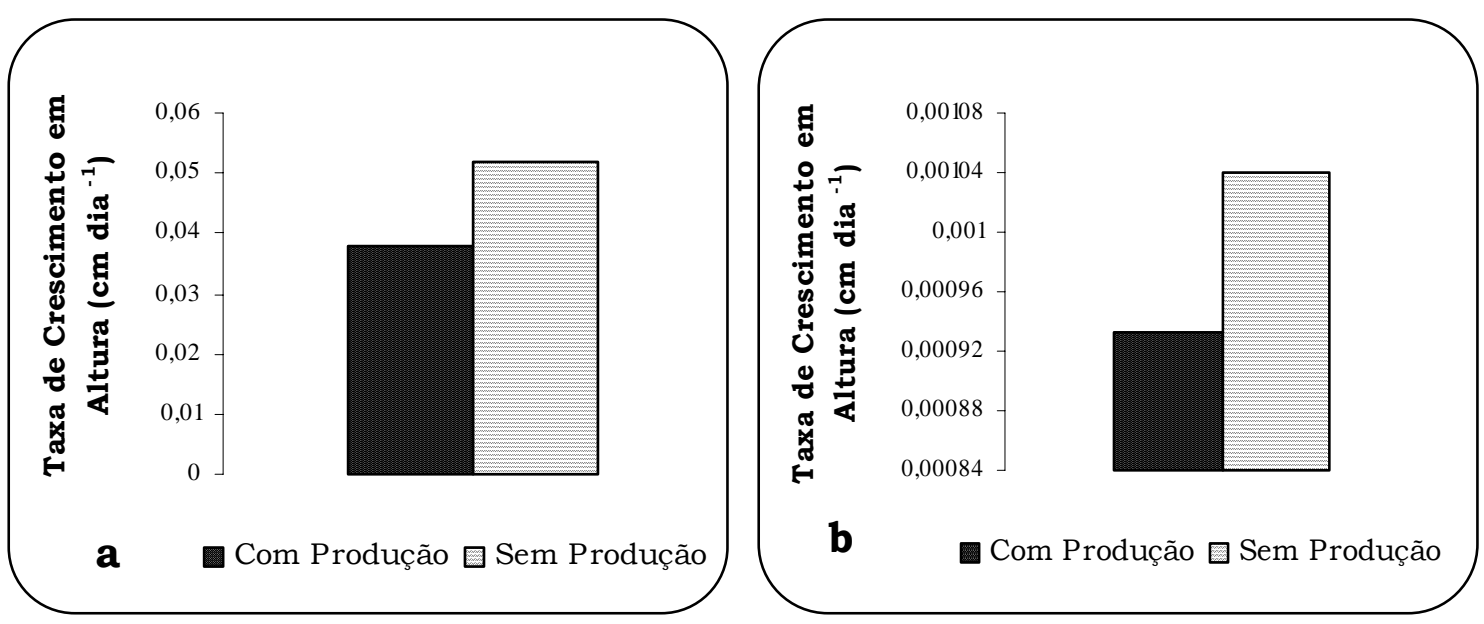

Figura 15 - Taxa de crescimento da altura (TCH; $\mathrm{cm}$ dia-1) das plantas com e sem produção de frutos, nos períodos entre as fases fenológicas E1 - E2 (frutos em "chumbinho" e em expansão) (a) e E3-E4 (b) (frutos em granação e em início da maturação)

A partir dos resultados obtidos pode-se afirmar que existe uma relação direta entre a síntese de fenóis e os estádios da frutificação, em 
razão da competição por carboidratos entre os metabolismos primário e secundário.

A taxa de crescimento vegetativo das plantas com carga pendente, em geral, foi menor comparativamente às plantas sem frutos, devido ao maior deslocamento de sacarose para a frutificação. A diminuição na mobilização de assimilados para os processos vegetativos nas plantas com frutos afetou, em conseqüência, o crescimento do cafeeiro. Portanto, os fotoassimilados produzidos pela fotossíntese das plantas (metabolismo primário) são distribuídos diferentemente entre os órgãos vegetativos e reprodutivos do cafeeiro.

\subsection{Teor foliar de fenóis em relação ao clima}

A variação dos teores de fenóis nas folhas dreno e nas folhas fonte durante as fases de frutificação em relação as variáveis climáticas preditoras como a temperatura atmosférica (média, máxima e mínima; $\left.{ }^{\circ} \mathrm{C}\right)$, a radiação global $\left(\mathrm{MJ} \mathrm{m}^{-2} \mathrm{dia}^{-1}\right)$ e a insolação diária (h dia $^{-1}$ ) é apresentada na Figura 16, 17 e 18, respectivamente.

\subsubsection{Temperatura atmosférica}

$\mathrm{Na}$ Figura 16 constata-se que existe correlação entre as concentrações de fenóis e as temperaturas. A síntese de fenóis apresenta uma tendência inversa a temperatura, diminuindo os teores dessa substância na medida em que aumenta a temperatura atmosférica. Estes dados evidenciam que a produção de fenóis está relacionada de maneira indireta com a temperatura, independentemente dos valores máximo, mínimo e médio da mesma. Essa afirmação (ação indireta), se fundamenta na dependência do metabolismo secundário em relação ao primário, cuja resposta aos fatores bióticos e ou abióticos depende do grau de interferência na atividade do metabolismo principal. 

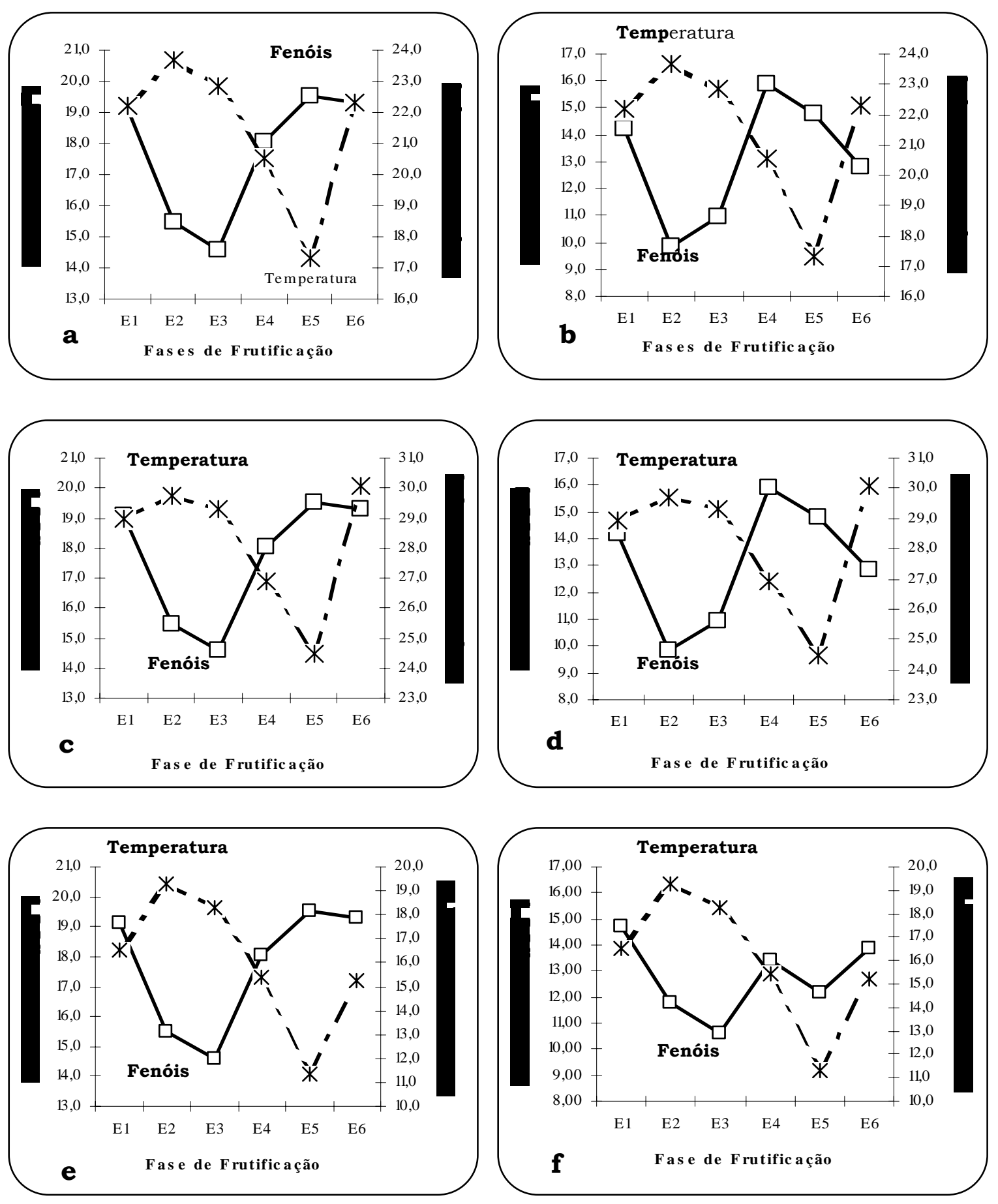

Figura 16 - Teores de fenóis totais $\left(\mu g \mathrm{~g}^{-1}\right)$ nas folhas dreno (a, c, e) e folhas fonte $(b, d, f)$ das plantas com produção em razão das fases fenológicas da frutificação e da variação da temperatura (média, máxima e minima; ${ }^{\circ} \mathrm{C}$ ) 
Nos períodos E2 (frutos em expansão) e E3 (frutos em granação), quando as temperaturas são mais elevadas, com temperatura média de $23^{\circ} \mathrm{C}$ (Figura 16 a), o crescimento vegetativo das plantas sem produção de café é maior, conforme verificado nas Figuras 13 e 14. Assim, a temperatura afeta indiretamente os teores de fenóis totais, os quais decrescem nesses períodos, devido à competição por carboidrato.

As plantas com produção demandam maiores quantidades de carboidratos para o crescimento do fruto nos períodos de expansão e granação, a qual varia com condições climáticas como a temperatura, radiação e água. Portanto, tanto os frutos como o crescimento vegetativo em cafeeiros em formação, como no presente experimento, se alternam como drenos de açúcares, competindo com o metabolismo secundário, por reduzir o saldo de sacarose e, assim, a síntese de fenóis. Na cultura do café essa afirmação se justifica uma vez que as fases vegetativas e reprodutivas ocorrem concomitantemente.

\subsubsection{Radiação Global}

A radiação global $\left(\mathrm{MJ} \mathrm{m}^{-2}\right.$ dia-1$\left.^{-1}\right)$ e a síntese de fenóis totais $\left(\mu \mathrm{g} \mathrm{g}^{-1}\right)$ apresentaram comportamento semelhante aquele verificado para a temperatura, ou seja, variam inversamente conforme pode ser visualizado na Figura 17. A explicação para essa relação se deve ao fato de que a temperatura atmosférica é uma medida de calor dependente da quantidade de energia no ambiente determinada por meio da radiação global (MJ m${ }^{-2}$ dia $\left.^{-1}\right)$. 

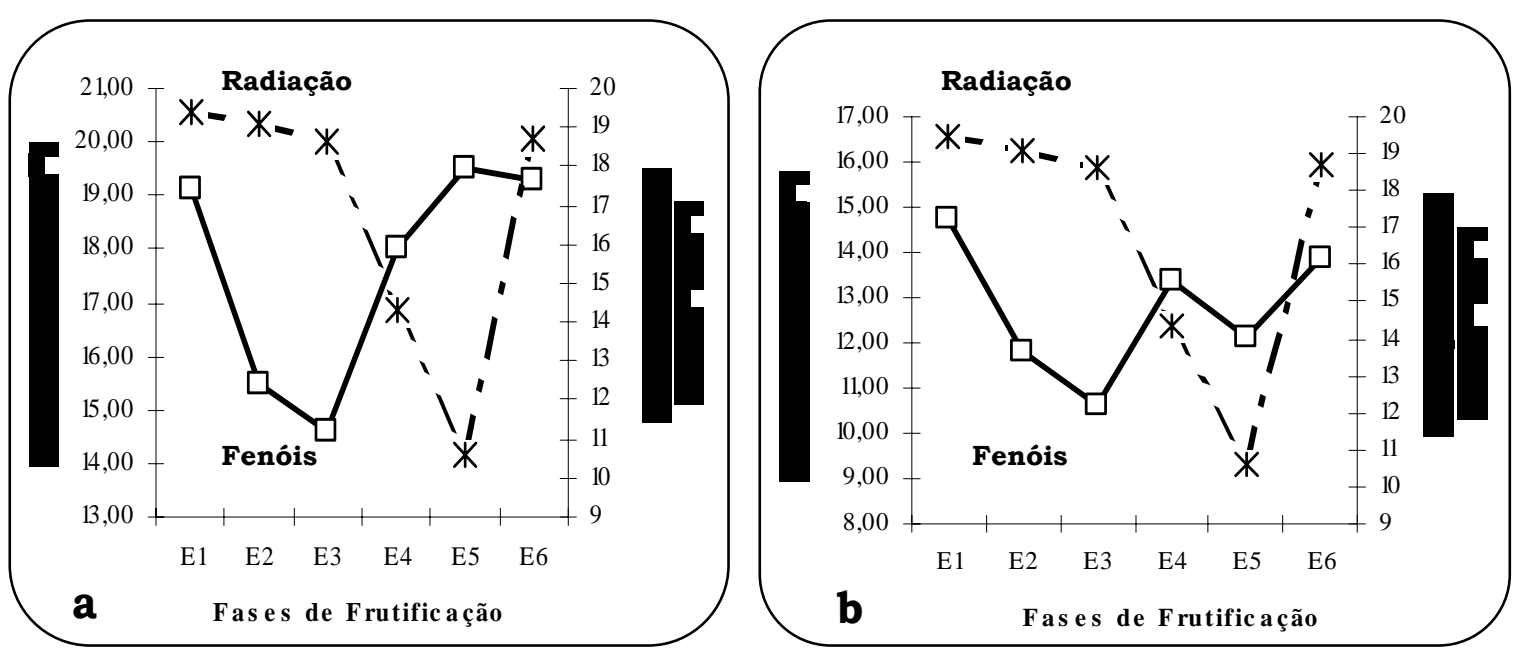

Figura 17 - Teores de fenóis totais $\left(\mu \mathrm{g} \mathrm{g}^{-1}\right)$ nas folhas dreno (a) e fonte (b) das plantas com produção em razão das fases fenológicas de frutificação e da variação da radiação global $\left(\mathrm{MJ} \mathrm{m}^{-2} \mathrm{dia}^{-1}\right)$

\subsubsection{Insolação diária}

Para essa variável preditora (insolação diária; $h$ dia $^{-1}$ ) não foi constatada correlação com o teor de fenóis totais, o qual não apresentou um padrão de comportamento durante as fases de frutificação do cafeeiro (Figura 18). 

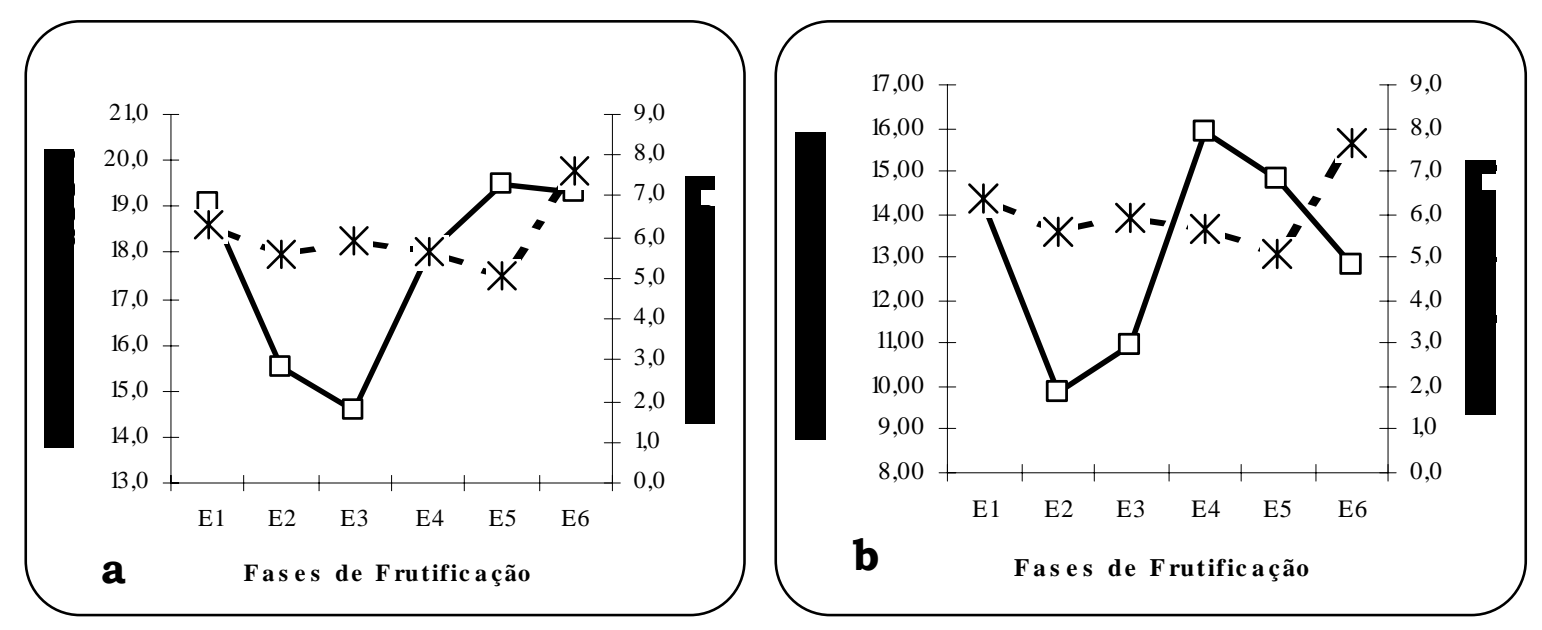

Figura 18 - Teores de fenóis totais $\left(\mu g g^{-1}\right)$ nas folhas dreno (a) e fonte (b) das plantas com produção em razão das fases fenológicas de frutificação e da variação da insolação diária (h dia-1)

Considerando a variação da sintese de fenóis em relação às variáveis climáticas preditoras (temperatura atmosférica - ${ }^{\circ} \mathrm{C}$; radiação global - MJ m dia $^{-1}$; insolação diária - $\mathrm{h}$ dia ${ }^{-1}$ ) pode-se admitir que a sintese desses compostos está associado ao clima (temperatura atmosférica e radiação global). Porém, não se pode afirmar que essas variáveis climáticas influenciem diretamente a produção de fenóis, pois o metabolismo secundário depende do saldo de carboidrato, que varia com a demanda dos drenos - frutos em formação e ou crescimento vegetativo. Essas fases (frutificação e vegetação) as quais ocorrem concomitantemente e estão diretamente relacionadas com o metabolismo primário - fonte de carboidratos (fotossintese) depende, fundamentalmente, das condições climáticas. 


\section{CONCLUSÕES}

* A quantidade de fenóis totais não varia em função da produção de frutos pelo cafeeiro em formação.

* Nas fases de expansão e granação dos frutos, no período correspondente de dezembro a março, diminuiu a sintese de fenóis totais.

* As folhas novas (dreno) contêm menores teores de fenóis totais em relação às folhas maduras (fonte).

* A sintese de fenóis totais depende, indiretamente, da temperatura $\left({ }^{\circ} \mathrm{C}\right)$ e da radiação global $\left(\mathrm{MJ} \mathrm{m} \mathrm{m}^{-2} \mathrm{dia}^{-1}\right)$, apresentando tendência inversa em relação a estas variáveis climáticas.

* A orientação do manejo fitossanitário deve considerar as épocas em que há comprometimento da defesa natural da planta, em relação a produção de substâncias protetivas - os fenóis. 


\section{REFERÊNCIAS BIBLIOGRÁFICAS}

AGRIOS, G.N. Plant Pathology 4. ed. San Diego: Academic Press, 1997. 635p.

AMARAL, J.A.T. Crescimento vegetativo estacional do cafeeiro e suas interações com fontes de nitrogênio, fotoperiodo e assimilação do nitrogênio. Viçosa, 1991. 139p. Tese (Doutorado) - Universidade Federal de Viçosa.

AMORIM, H.V. The effect of nitrogen and carbohidrat on production of phenols by plant cell cultures. Ohio, 1970. 55p. Dissertação - The Ohio University.

BANZATTO, D. A.; KRONKA, S. do N. Experimentação agricola. Jaboticabal: FUNEP, 1992. 247p.

BASHAN, Y. Phenols in cotton seedlings resistant and susceptible to Alternaria macrospora. Journal of Phytopathology, n.116, p.1-10, 1986.

BATAGLIA, O.C.; FURLANI; A.M.C.; TEIXEIRA, J.P.F.; FURLANI; P.R.; GALLO, J.R. Métodos de análises químicas de plantas. Campinas: Instituto Agronômico, 1983. 48 p. (Boletim Técnico, 78) 
BAZZALO, M.E.; HEBER, E.M.; DEL PERO MARTINEZ, M.A.; CASO, H.O. Phenolic compounds in stems of sunflower plants inoculated with Sclerotinia sclerotiorum and their inhibitory effects on the fungus. Pythopathology Zeitschrift, n.112, p.322-332, 1985.

BECKMAN, C.H. Phenolic-storing cells: Keys to programmed cell death and periderm formation in with disease resistance and in general defense responses in plants? Physiological and Molecular Plant Pathology, v.57, p.101-110, 2000.

BOL, J.F.; LINTHORST, H.J.M; CORNELISSEN, B.J.C. Plant pathogenesis-related proteins induced by virus infection. Annual Review of Phytopathology, v.28, p.113-138, 1990.

BONNET, J.A. Influence of varieties and seasons upon mineral nutrient levels of coffee leaves from Puerto Rico. Journal of Agriculture University of Puerto Rico, v.53, n.3, p.177-186, 1969.

CAMARGO, A.P.; CAMARGO, M.B.P. Definição e esquematização das fases fenológicas do cafeeiro arábica nas condições tropicais da Brasil. Bragantia, v.60, n.1, p.65-68, 2001.

CANNAS, A. Tannins: fascinating but sometimes dangerous molecules. Itaka, 1999. http://www.ansci.cornell.edu/plants/toxicagents/tannin.htm (30 março 2003). 
CANNELL, M.G.R. Physiology of the coffee crop. In: CLIFFORD, M.N.; WILSON, K.C. (Ed). Coffee: botany, biochemistry and production of beans and beverage. London: The AVI, 1985. p.108-134.

CARVALHO, A.; KRUG, C. A.; MENDES, J.E.T. O dimorfismo dos ramos em Coffea arabica L. Bragantia, v.10, p.151-159, 1950.

CARVALHO, V.L. de; CHALFOUN, S.M.; CASTRO, H.A. de. Influência de diferentes niveis de produção sobre a evolução da ferrugem do cafeeiro e sobre teores foliares de compostos fenólicos. Ciência Agrotécnica, v.25, n.1, p.49-54, jan./fev. 2001.

CHALFOUN, S.M.; CARVALHO, V.L. de; SATURNINO, H.M.; CARVALHO, V.D. de. Teores de compostos fenólicos em películas de bulbilhos de coloração normal e alterada de cultivares de alho. Pesquisa Agropecuária Brasileira, v.30, n.9, p.1163-1166, set. 1995.

CHAVES, J. C.D; SARRUGE, J.R. Alterações nas concentrações de macronutrientes nos frutos e folhas do cafeeiro durante o ciclo produtivo. Pesquisa Agropecuária Brasileira, v.19, n.4, p.427-432, 1984.

COLEY, P.D. Patterns of defence in plants: why do herbivores prefer certain species? Revista de Biologia Tropical, v.35, n.1, p.151-164, 1987. 
CONTI, G.G.; BASSI, M.; MAFFI, D.; BOCCI, A.M. Host-parasite relationship in a susceptible and a resistant rose cultivar inoculated with Sphaerotheca pannosa. II. Deposition rates of callose, lignin and phenolics in infected or wounded cells and their possible role in resistance. Journal of Phytopathology, n.117, p.312-320, 1986.

CREASY, L.L The role of low temperature in anthocyanin synthesis in "McIntosh" apples. Proc. American Society Horticultural Science, n. 93, p.716-724, 1968.

DEOTALE, R.D.; KENE, D.R.; BAKALE, V.L.; PATIL, B.N. Biochemical changes in subabul (leucaena leucocephala (Lam.) de Wilt) foliage by application of fertilizers and hormones. Advances in Agricultural Research in India, v.1, p.134-145, 1994.

ESGUERRA, E.B.; KAWADA, K.; KITAGAWA, H. Ripening behaviour of "Senorita" bananas at different temperatures. ASEAN Food Journal, v.7, n.2, p.79-85, 1992.

FARKAS, G.L.; KIRALY, Z. Role of phenolic compounds in the physiology of plant diseases and diasease resistance. Phytopathologische Zeitschrift, v.44, p.105-150, 1962.

FAZUOLI, L.C. Genética e melhoramento do cafeeiro. In: RENA, A. B.; MALAVOLTA, E.; ROCHA, M.; YAMADA, T. (Ed). Cultura do cafeeiro: Fatores que afetam a produtividade do cafeeiro. Piracicaba: POTAFÓS, 1986. p.87-113. 
FIGUEIRÊDO, J.M. Compostos fenólicos e fitoalexinas em hipocótilos e raízes de feijoeiro inoculados com Fusarium solani f. phaseoli (Burk) Snyd. E Hans. Piracicaba, 1975. 55p. Dissertação (Mestrado) Escola Superior de Agricultura "Luiz de Queiroz", Universidade de São Paulo.

FRIEND, J. Plant phenolics, lignification and plant diseases. In: Progress in Phytochemistry, n.7. p.197-261, 1981.

GETACHEW, G. Tannins in tropical multipurpose tree species: localization and quantification of tannins using histochemical approaches and the effect of tannins on in vitro rumen fermentation. Stuttgart: Verlag Ulrich E. Grauer, 1999. 186p.

GOODMAN, R.N.; KIRALY, Z.; WOOD, K.R. The Biochemistry and physiology of plant disease. Columbi: University of Missouri Press, 1986. 443p.

GRAVENA, S. Manejo ecológico de pragas do cafeeiro. In: CURSO DE ATUALIZAÇÃO EM CAFÉ 3., Campinas: Consórcio brasileiro de pesquisa e desenvolvimento do café, 2003. p.16-37.

HILLIS, W.E. Shikimic acid in the leaves of Eucalyptus sieberiana. F. Muell. Journal Experimental Botany. n. 10, p. 87-89, 1959.

HONNER, J.D. Astringency of Douglas-fir foliage in relation to phenology and xylem pressure pontencial. Journal of Chemical Ecology, v.14, n.4, p.1227-1237, 1988. 
HRAZDINA, G. Compartimentation in phenolic metabolism. Acta Horticulturae, v.1, n.381, p.8693, 1994.

ISAAC, S. Fungal and plant interactions. Cambridge: Chapman and hall, 1992. 418p.

JARAMILLO, R.; VALÊNCIA, G. Los elementos climáticos y el desarrollo de Coffea arabica L. em Chinchina. Cenicafé, v.3, n.3, p.80-104, jul./set. 1980.

JOHNSON, J.D.; TOGNETTI, R.; MICHELOZZI, M.; PINZAUTI S.; MINOTTA, G.; BORGHETTI, M. Ecophysiologycal responses of Fagus sylvatica to changing light conditions. II. The interactions of light environment and soil fertility on seedling physiology. Physiologia Plantarum, v.101, n.1, p.124-134, 1997.

KUC, J.; PRESSIG, C. Fungal regulation of disease resistance mechanisms in plants. Mycologia, v.76, p.767-784, 1984.

KOSUGE, T. The role of phenolics host response to infection. Annual Review of Phytopathology, v.7, p.195-222, 1969.

LEES, G.L.; GRUBER, M.Y.; SUTTILL, N.H. Condensed tannins in sainfoin. II. Ocurrence and changes during leaf development. Canadian journal of Botany, v.73, n.10, p.1540-1547, 1995.

MALAVOLTA, E. Nutrição mineral e adubação do citros. Boletim técnico Instituto Potassa. v.5, p.13-71, 1979. 
MASOODI, M.A. Growth response of Lymantria obfuscata Walker in relation to tannin content in different host foliages. Indian Journal of Entomology, v.47, n.4, p.422-426, 1985.

MAYAMA, S.; SHISHIYAMA, J. Localized accumulation of fluorescent and U.V. absorbing compounds at penetration sites in barley leaves infected with Erysiphe graminis hordei. Physiological Plant Pathology, n.13, p.347, 1978.

MES, M. G. Estudos sobre o florescimento de Coffea arabica L. New York: IBEC Research Institute, n.14, p.48, 1957.

MISAGHI, I.J. Physiology and biochemistry of plant-pathogen interactions. New York: Plenum Press, 1980. 205p.

MORAES, W.B.C.L.; MUSUMECI, M.R.; CONTI, E. de; GROHMANN, A.; MARTINS, E.M.F. Aspectos do mecanismo bioquimico de resistência de cafeeiros ao fungo Hemileia vastatrix. In: REUNIÃO ANUAL DA SOCIEDADE BRASILEIRA DE FITOPATOLOGIA 4., Piracicaba, 1971. Anais. Piracicaba: Sociedade Brasileira de Fitopatologia, v.4, 1971. p.27-28.

NACACCHE, V.M. Alterações bioquímicas em folhas de Coffea arabica resistentes e suscetiveis à infecção por Hemileia vastatrix (Ferrugem do café). São Paulo, 1983. 113p. Tese (Doutorado) - Escola Paulista de Medicina, Depto. de Bioquímica, Universidade Federal de São Paulo. 
NATIONAL RESEARCH COUNCIL. Ecologically based pest management: new solutions for a new century, 1996. 144p.

NICHOLSON, R.L.; HAMMERSCHMIDT, R. Phenolic compounds and their role in disease resistance. Annual Review of Phytopathology, v.30, p.369-389, 1992.

OLIVEIRA, R.F. de. A planta sob estresse. In: CURSO DE ATUALIZAÇÃO EM CAFÉ 3., Campinas: Consórcio brasileiro de pesquisa e desenvolvimento do café, 2003. p.44-50.

OLIVEIRA, J.R. de; ROMEIRO, R. da S. Compostos fenólicos, idade da folha e resistência do cafeeiro a Pseudomonas cicgorii e Pseudomonas syringae, pv. Garcae. Revista Ceres, v.38, n.220, p.445-452, 1991.

PASCHOLATI, S.F.; LEITE, B. Hospedeiro: mecanismo de resistência. In: LUZ, W. C. (Ed.). Revisão Anual de Patologia de Plantas, v.2. p.1-51, 1994.

PITTA, F.A. de O.; JUNQUEIRA, N.T.V.; ALFENAS, A.C.; CANO, M.A.O. Regulação fenólica da resistência a infecção por Microcylus ulei Henn V. Arx em progênie de Hevea. Pesquisa Agropecuária Brasileira, n.28, v.8, p.1193-1200, ago. 1990.

RAIJ, B.V.; CANTARELLA, H.; QUAGGIO, J.A.; FURLANI, A.M.C. Recomendação de adubação e calagem para o Estado de São Paulo. Campinas: IAC, n.100, 1996. 258p. (Boletim técnico) 
RENA, A.B. Adubação de inverno no cafeeiro. Lavras: EPAMIG, Circular técnico, n.120, 2000. 2p.

RENA, A.B.; MAESTRI, M. Fisiologia do cafeeiro. In: RENA, A. B.; MALAVOLTA, E.; ROCHA, M.; YAMADA, T. (Ed). Cultura do cafeeiro: Fatores que afetam a produtividade do cafeeiro. Piracicaba: POTAFÓS, 1986. p.13-85.

RENA, A.B.; MAESTRI, M. Ecofisiologia do cafeeiro. In: CASTRO, R.C.; FERREIRA, S.O.; YAMADA, T. (Ed). Ecofisiologia do cafeeiro. Piracicaba: Associação Brasileira para Pesquisa da Potassa e do Fosfato, 1987. p.119-147.

RODRIGUES JUNIOR, C.J. Mecanismo de resistência das plantas a patógenos. Lisboa: Imprensa Portuguesa, 1980. p.67.

RODRIGUES, W.A.; PAIVA, E.; SANTOS, F.G. dos; RODRIGUES, J.A. dos S. Variabilidade para teor em sorgo (Sorghum bicolor L.) e sua associação com a resistência a pássaros. Ciência e prática, v.16, n.1, p.74-77, jan./mar. 1992.

SARRUGE, J.R.; HAAG, H.P. Análises químicas em plantas. Piracicaba: ESALQ, 1974. 57p.

SHIMONI, M.; BAR-ZUR.; REUVENI, R. The association of peroxidase activity and resistence of maize to Exserohilum turcicum. Journal Phytopathology, v.131. p.315-321, 1991. 
STRACK, D. Phenolic metabolism. In: DEY, P. M.; HARBONE, J. B. (Ed.). Plant Biochemistry. London: Academic Press, 1997. cap.10, p.387-416.

TAIZ, L.; ZIEGER, E. Plant physiology. California: The Benjamin/Cummings, 1991. 559p.

VIDHYSEKARAN, P. Physiology of disease resistance in plants. v.I. Boca Raton: CRC Press, 1988. 149p.

YUSOF, S.; MOHAMED, S.; ABU-BAKAR, A. Effect of fruit maturity on the quality and acceptability of Guava puree. Food Chemistry, v.30, n. 1, p.45-58, 1988.

ZULUAGA, V.J.; VALÊNCIA, A.G.; GONZALEZ, J. Contribucíon al estudio de la natureza de la resistencia del cafeto a Ceratocystis fimbriata (El1. Halst). Hunt. Cenicafé, v.2, n.22, p.43-68, 1971.

WATANABE, R.; CHORNEY, W.; SKOK, J.; WENDER, S.H. Effect of boron deficiency on polyphenol production in the sunflower. Phitochem, n.3, p.391-393, 1963. 